\title{
THE CHINESE WALL DEFENSE TO LAW-FIRM DISQUALIFICATION
}

American law firms have grown to unprecedented size by branching, merging, and expanding internally. ${ }^{1}$ This growth has inevitably magnified the potential for intrafirm conflicts of interest. As a firm increases in size, and the number of its lawyers and past and present clients grows, there is a greater likelihood that prospective clients will have interests adverse to those of other clients, both current and former. ${ }^{2}$ In these circumstances, representation may lead to disqualification based on a lawyer's duties to protect a client's confidences and secrets, ${ }^{3}$ to serve a client with undivided loyalty, ${ }^{4}$ and to avoid even the appearance of impropriety. ${ }^{5}$ If an ethical conflict is found sufficient to disqualify an individual attorney, then, under traditional rules, the disqualification may extend to the entire firm with which he or she is associated. ${ }^{6}$ In particular, confidences and secrets obtained by a single attorney in an adverse

1 As of October, 1979, there were 11 American law firms with more than 200 attorneys, and 38 firms with more than 150 attorneys. National Law Firm Survey, Nat'l L.J., Oct. 1, 1979, at 28-33 [hereinafter cited as Survey]. See Cantor, Law Firms Are Getting Bigger . . . and More Complex, 64 A.B.A.J. 215, 215-19 (1978); Bodine, Mammoth Firm Keeps Steamrolling, Nat'l L.J., Aug. 13, 1979, at 1, col. 4; Lewin, Law Firms Branch Out, Go National, Nat'l L.J., Aug. 7, 1978, at 1, col. 4 .

2 "The risk of conflict rises exponentially with the size of the firm . . . ." G. Hazard, Ethics IN the Practice of Law 81 (1978); see Note, Unchanging Rules in Changing Times: The Canons of Ethics and Intra-Firm Conflicts of Interest, 73 Y YLE L.J. 1058, 1068 (1964) [hereinafter cited as Intra-Firm Conflicts]. See also Tybor, Conflicts: When Big Isn't Better, Nat'l L.J., May 7, 1979, at 1, col. 4; 17, col. 2.

3 "A Lawyer Should Preserve the Confidences and Secrets of a Client." ABA Code of Professional Responsubitity, Canon 4. [The Code of Professional Responsibility, its Canons, Ethical Considerations, and Disciplinary Rules, are hereinafter cited, respectively, as CoDE, Canon, EC, and DR.]

4 "A Lawyer Should Exercise Independent Professional Judgment on Behalf of a Client." Canon 5.

5 "A Lawyer Should Avoid Even the Appearance of Professional Impropriety." Canon 9.

${ }^{6}$ Disciplinary Rule 5-105(D) of the Code has been relied upon by courts in disqualification proceedings as a firm-disqualification rule. It reads: "If a lawyer is required to decline employment or to withdraw from employment under a Disciplinary Rule, no partner, or associate, or any other lawyer affliated with him or his firm, may accept or continue such employment." See, e.g., Armstrong v. McAlpin, 606 F.2d 28 (2d Cir. 1979), rehearing en banc granted, No. 79-7042 (Dec. 12, 1979).

Although DR 5-105(D) in its present form dates back only to 1974, see text accompanying notes 69-72 infra, the rule it embodies has long been observed by courts in disqualification proceedings. See sources cited in ABA CoMm. on ETHICs \& Professional Responsuburty, Opinions, No. 342 (1975) [hereinafter cited as ABA OpINIon 342], reprinted in 62 A.B.A.J. 517, 517 n.2 (1976). 
representation may disqualify every member of his or her law firm, by means of a presumption that everyone shares in the "infected" attorney's knowledge. ${ }^{7}$

With increasing frequency, law firms faced with the possibility of disqualification have attempted to rebut this presumption of imputed knowledge by adopting procedures designed to create an impermeable barrier to intrafirm exchange of confidential information. Called "screens" or "Chinese walls," these procedures aim to isolate the disqualification to the lawyer or lawyers infected with the privileged information that is the source of the ethical problem, and thereby to allow other attorneys in the firm to carry on the questioned representation free of any taint of misuse of confidences. Typical walling procedures include prohibiting the tainted attorney(s) from having any connection with the case or receiving any share of the fees attributable to it, banning relevant discussions with or the transfer of relevant documents to or from the tainted attorney(s), restricting access to files, educating all members of the firm as to the importance of the wall, and separating, both organizationally and physically, groups of attorneys working on conflicting matters.

Although courts have mostly looked askance at the Chinese wall defense to firm disqualification, ${ }^{8}$ their examinations of the issue have been largely superficial. Many commentators writing about disqualification mention Chinese walls but either pay them insufficient attention or fail to analyze them adequately.9 A typically

T See, e.g., Schloetter v. Railoc, Inc., 546 F.2d 706, 710 (7th Cir. 1976); Silver Chrysler Plymouth, Inc. v. Chrysler Motors Corp., 518 F.2d 751, 754 (2d Cir. 1975).

8 See Armstrong v. McAlpin, 606 F.2d 28 (2d Cir. 1979), rehearing en banc granted, No. 79-7042 (Dec. 12, 1979); Westinghouse Elec. Corp. v. Kerr-McGeo Corp., 580 F.2d 1311 (7th Cir.), cert. denied, 439 U.S. 955 (1978); Fund of Funds, Ltd. v. Arthur Andersen \& Co., 567 F.2d 225 (2d Cir. 1977). But see Kesselhaut v. United States, 555 F.2d 791 (Ct. Cl. 1977) (en banc). See also Central Milk Prods. Coop. v. Sentry Food Stores, Inc., 573 F.2d 988, 991-93, 993 (8th Cir. 1978) (discussion of screening procedures not to be construed as approving practice that probes "outer limits of ... professional conduct"); Hull v. Celanese Corp., 513 F.2d 568, 571-72 (2d Cir. 1975) (screening argument "somewhat technical" and overlooked "the spirit of Canon 9"); W.E. Bassett Co. v. H.C. Cook Co., 201 F. Supp. 821, 824 (D. Conn. 1961), aff'd per curiam, 302 F.2d 268 (2d Cir. 1962) (firm disqualified although it "took particular pains" to segregate disqualified partner).

9 See, e.g., G. HAzARD, supra note 2, at 113; Aronson, Conflict of Interest, 52 WAsr. L. Rev. 807, 848, 855 (1977); Lacovara, Restricting the Private Practice of Former Government Lawyers, 20 ARIz. L. REv. 369 (1978); Liebman, The Changing Law of Disqualification: The Role of Presumption and Policy, 73 Nw. U. L. Rev. 996, 1019-20 (1979); Note, The Former Government Attorney and the Code of Professional Responsibility: Insulation or Disqualification, 26 CATH. U. L. Rev. 402 (1977) [hereinafter cited as Insulation or Disqualification]; Note, Ethical Problems for the Law Firm of a Former Government Attorney: Firm or Individual Dis- 
glib, though wickedly funny, example is Professor Hazard's remark that ' ' $[w]$ alling off' is thus like the alleged New England practice of bundling, having neither the credibility of real prophylaxis nor the dignity of real self-control." 10

This dearth of analysis is disturbing if only because of the severe consequences that follow from law-firm disqualification. Disqualification restricts the client's right to counsel of its own choice, delays the resolution of litigation, and subjects the client to higher costs. ${ }^{11}$ Mechanical application of firm disqualification rules can also have undesirable effects beyond the confines of any particular litigation. Imputing knowledge of confidential information to all those associated with a firm may operate to restrict the mobility of attorneys because a hiring decision may subject an attorney's new law firm to disqualification in any representation adverse to the clients of that attorney's old firm. ${ }^{12}$ Such a result is especially troubling when the former employer is a public agency-few young lawyers will be eager to join government service if their opportunities for future employment in the private sector are thereby curtailed. ${ }^{13}$ In addition to these restraints on mobility, it is conceivable that strict firm-disqualification practices will ultimately serve to inhibit the

qualification, 1977 Doke L.J. 512; Comment, Conflicts of Interest and the Former Government Attorney, 65 Gro. L.J. 1025 (1977); Note, Business as Usual: The Former Government Attorney and ABA Disciplinary Rule 5-105(D), 28 Hastings L.J. 1537 (1977) [hereinafter cited as Business as Usual]; Note, Westinghouse Electric Corp. v. Kerr-McGee Corp.: Attorney Disqualification for Conflict of Interest, 10 Loy. CrI. L.J. 271 (1979); Note, Motions to Disqualify Counsel Representing an Interest Adverse to a Former Client, 57 TEXAS L. REv. 726 (1979); Comment, Access to Work Product of Disqualified Counsel, 46 U. CEr. L. REv. 443 (1979); 82 Dick. L. REv. 625 (1978); 28 EMORY L.J. 215 (1979); 30 OKL.A. L. Rev. 365 (1977); 12 SuFfolx L. Rev. 189 (1978).

$10 \mathrm{G}$. HAZARD, supra note 2, at 113 . Contrary to the import of Professor Hazard's assertion, lawyers are neither scoundrels for whom nothing short of "real prophylaxis" is needed, nor are they morally superior patricians, to whom anything less than "real self-control" is an affront to dignity. Indeed, if either of these extreme characterizations were correct, a code of professional ethics would be superfluous. As ordinary, fallible human beings, conscientious lawyers may well draw strength both from the reduced opportunity for ethical error that walling off aims to achieve and from the wall's function as a constant reminder of the lawyer's professional responsibility.

11 Hull v. Celanese Corp., 513 F.2d 568, 572 (2d Cir. 1975); Emle Indus., Inc. v. Patentex, Inc., 478 F.2d 562, 565 (2d Cir. 1973); American Can Co. v. Citrus Feed Co., 436 F.2d 1125, 1129 (5th Cir. 1971); see Comment, The Avail ability of the Work Product of a Disqualified Attorney: What StandardP, 127 U. PA. L. Rev. 1607, 1630-35 (1979) [hereinafter cited as Work Product.]

12 See, e.g., Silver Chrysler Plymouth, Inc. v. Chrysler Motors Corp., 370 F. Supp. 581 (E.D.N.Y. 1973), affd, 518 F.2d 751 (2d Cir. 1975); Intra-Firm Conflicts, supra note 2 , at $1069-72$.

13 See Kaufman, The Former Government Attorney and the Canons of Professional Ethics, 70 HARV. L. REv. 657, 657 (1957); sources cited in note 9 supra. 
size of law firms, ${ }^{14}$ unduly restricting their ability to meet the changing needs of legal practice.

This Comment begins by analyzing in part I the purpose of the Chinese wall defense and the kinds of ethical problems with respect to which it can meaningfully be employed. Part II canvasses the case law on Chinese walls, with particular focus on Armstrong v. McAlpin, ${ }^{15}$ a recent decision by the Court of Appeals for the Second Circuit. Having concluded that existing precedent supports, or at least does not foreclose, acceptance of the Chinese wall defense in certain kinds of cases, the discussion then turns in part III to the extensive experience of financial institutions with the Chinese wall solution to conflicts of interest. A comparison of law-firm walls with walls in financial institutions leads to the conclusion that, in general, Chinese walls will be sufficiently effective to rebut the presumption that all members of a law firm share in a client's confidences. But because the risk of disclosure or misuse of confidences and secrets is a question of fact, the success or failure of the Chinese wall defense must turn on the facts and circumstances of each case. A compendium of the factors influencing that determination serves as the focus of part IV.

\section{Bagkground: Disqualification Motions}

Although judicial encounters with the Chinese wall defense to firm disqualification have been few, they suffice to demonstrate confusion over which types of offenses Chinese walls might conceivably work to remedy. It thus becomes necessary to begin with a preliminary overview of the law on disqualification motions. ${ }^{16}$ For this purpose, it is helpful to distinguish between disqualification

14 See Intra-Firm Conflicts, supra note 2, at 1069-72. Of course, other internal factors may limit the growth of law firms. See Bodine, supra note 1. 12, 1979).

15606 F.2d 28 (2d Cir. 1979), rehearing en banc granted, No. 79-7042 (Dec.

16 The subject has been explored in detail in recent literature. In addition to the sources cited in note 9 supra, see R. WISE, LEGAI ETrrcs (Supp. 1977); Morgan, The Evolving Concept of Professional Responsibility, 90 HARv. L. Rev. 702 (1977); O'Toole, Canon 9 of the Code of Professional Responsibility: An Elusive Ethical Guideline, 62 MarQ. L. Rev. 313 (1979); Symposium, The Legal Profession, 20 Aruz. L. REv. 361 (1979); Symposium, Reflections on a Decade Under the Code of Professional Responsibility: The Need for Reform, 57 N.C. L. Rev. 497 (1979); Symposium, American Bar Association Code of Professional Responsibility, 48 Texas L. Rev. 255 (1970); Note, Attorney's Conflict of Interests: Representation of Interest Adverse to That of Former Client, 55 B.U. L. REv. 61 (1975); Note, Disqualification of Counsel for the Appearance of Professional Impropriety, 25 CATr. U. L. REv. 343 (1976); Note, Ethical Considerations When an Attorney Opposes a Former Client: The Need for a Realistic Application of Canon Nine, 52 ChH.-Kent L. Rev. 525 (1975); Note, The Second Circuit and Attorney Disqualification-Silver Chrysler Steers in a New Direction, 44 FordHais 
motions arising out of an attorney's acceptance of employment against a former client (successive representation) and those arising out of employment against an existing client (concurrent representation). In the successive representation context, the chief ethical concern, addressed in Canon 4, is that confidential information relating to the former client will be disclosed or used to his disadvantage. Although the same danger is implicated in concurrent representation cases, there an additional ethical concern is present -the attorney's Canon 5 duty to serve his or her client with undivided loyalty. ${ }^{17}$ In both types of situations, Canon 9's command to avoid even the appearance of impropriety applies.18

The standard for disqualification of an individual attorney in a successive representation case was announced by Judge Weinfeld more than twenty-five years ago. ${ }^{19}$ If the matters embraced by the adverse representations are "substantially related," the attorney must be disqualified, even though it has not been shown that the attorney was in fact privy to the former client's confidences. ${ }^{20}$

L. REv. 130 (1975); Note, Appearance of Impropriety as the Sole Ground for Disqualification, 31 U. MrAMI L. Rev. 1516 (1977).

The research on which this Comment is based is limited to civil cases in the federal courts.

17 Although an attorney's Canon 5 duty to serve a client with undivided loyalty survives the termination of the attorney-client relationship and may disqualify him or her from accepting a subsequent adverse representation, that ethical problem for the most part will have no effect on the question of the firm's disqualification and need not be discussed further in this Comment. See ABA Comm'n on Evaluation of Professional Standards, Moder Rules of Professional Conduct $\$ 7.1$ (b) (2), Comment, at 110-11 (Discussion Draft, Jan. 30, 1980) [hereinafter cited as MoDeL RULEs]. In successive representation cases, the chief ethical concern relevant to law-firm disqualification is Canon 4's proscription on the disclosure or misuse of client confidences and secrets. See Work Product, supra note 11, at 1615 n.52.

18 Disqualification cases involving government attorneys are often dealt with exclusively under Canon 9 because Canons 4 and 5 are premised upon the existence of an attorney-client relationship, see, e.g., Fred Weber, Inc. v. Shell Oil Co., 566 F.2d 602, 608 (8th Cir. 1977), cert. denied, 436 U.S. 905 (1978), overruled in part on other grounds, In re Multi-Piece Rim Prods. Liability Litig., No. 79-1781 (8th Cir. Jan. 7,1980 ) (en banc), an element lacking in the government context. The policies underlying those Canons nevertheless extend beyond the confines of the attorney-client relationship and may play a prominent role in Canon 9 analysis. See, e.g., Armstrong v. McAlpin, 606 F.2d 28 (2d Cir. 1979), rehearing en banc granted, No. 79-7042 (Dec. 12, 1979).

19 T.C. Theatre Corp. v. Warner Bros. Pictures, 113 F. Supp. 265, 268 (S.D. N.Y. 1953).

20 E.g., Schloetter v. Railoc, Inc., 546 F.2d 706, 710 (7th Cir. 1976); In re Yarn Processing Patent Validity Litig., 530 F.2d 83, 89 (5th Cir. 1976); American Roller Co. v. Budinger, 513 F.2d 982, 984 (3d Cir. 1975); Emle Indus., Inc. v. Patentex, Inc., 478 F.2d 562, 570 (2d Cir. 1973).

Note that the substantial relationship test is a rule of evidence, not an inexorable rule of law. Consolidated Theatres, Inc.' v. Warner Bros. Pictures, 216 F.2d 920, 924 (2d Cir. 1953); Redd v. Shell Oil Co., [1974-2] Trade Cas. 97 75,392, at 98,277 (D. Utah 1974), rev'd in part on other grounds, 518 F.2d 311 (10th Cir. 1975). 
Courts refuse to make a more direct inquiry into the lawyer's knowledge because to do so would require the party moving for disqualification to reveal the very confidences it wishes to keep secret. ${ }^{21}$ Traditionally, disqualification of an individual lawyer was understood to disqualify all lawyers affiliated with him or her, a rule now embodied in Disciplinary Rule 5-105 (D). ${ }^{22}$ With respect to misuse of confidences, this rule proceeds upon the assumption that a lawyer's knowledge of a client's confidences and secrets is shared by all the other lawyers in his or her firm. Although perhaps realistic enough in the days when law firms were smaller and practice less specialized, the validity of an irrebuttable presumption of shared confidences is today open to question..$^{23}$ Concern over the side effects of disqualification on the mobility of attorneys, coupled with other considerations, has led some courts to discard or limit this irrebuttable presumption in favor of a pragmatic approach. ${ }^{24}$

21 E.g., NCK Org'n v. Bregman, 542 F.2d 128, 134-35 (2d Cir. 1976); United States v. Standard Oil Co., 136 F. Supp. 345, 354-55 (S.D.N.Y. 1955); T.C. Theatre Corp. v. Warner Bros. Pictures, 113 F. Supp. 265, 269 (S.D.N.Y. 1953).

22 See note 6 supra \& accompanying text.

${ }^{23}$ See, e.g., Intra-Firm Conflicts, supra note 2, at 1069; 82 Drck. L. REv. 625, 628 (1978).

24 It is important to distinguish here between a number of different presumptions that the courts regularly confuse. The initial presumption is that an attorney who represents a client acquires actual knowledge of the client's confidences. Although such knowledge is presumed, courts often refer to it as "actual knowledge," perhaps because of the nearly universal view that the presumption is irrebuttable. See, e.g., Novo Terapeutisk Lab. A/S v. Baxter Travenol Labs., Inc., 607 F.2d 186, 197 (7th Cir. 1979) (en banc); Emle Indus., Inc. v. Patentex, Inc., 478 F.2d 562, 571 (2d Cir. 1973). But see City of Cleveland v. Cleveland Elec. Illum. Co., 440 F. Supp. 193, 209 (N.D. Ohio), aff'd mem., 573 F.2d 1310 (6th Cir. 1977), cert. denied, 435 U.S. 996 (1978); cf. Canadian Gulf Lines v. Triton Int'l Carriers, Ltd., 434 F. Supp. 691 (D. Conn. 1976) (although client swore he disclosed confidences to attorney, court was convinced that any such confidences were not "received" in the sense of being "cognitively processed or retained"). Some courts have found a way around this presumption by finding that the attorney in question did not really "represent" the client in the ordinary sense, but merely worked on peripheral matters. See, e.g., Silver Chrysler Plymouth, Inc. v. Chrysler Motors Corp., 518 F.2d 751, 756-57 (2d Cir. 1975).

A second presumption holds that an attorney having "actual knowledge" of a client's confidences shares that knowledge with all the other lawyers in his or her firm. Although some courts seem to have held this presumption irrebuttable, see, e.g., Arkansas v. Dean Food Prods. Co., 605 F.2d 380, 386 (8th Cir. 1979), overruled in part on other grounds, In re Multi-Piece Rim Prods. Liability Litig., No. 79-1781 (8th Cir. Jan. 7, 1980) (en banc); Westinghouse Elec. Corp. v. KerrMcGee Corp., 580 F.2d 1311, 1321 (7th Cir.), cert. denied, 439 U.S. 955 (1978); Schloetter v. Railoc, Inc., 546 F.2d 706, 710-11 (7th Cir. 1976); Laskey Bros. v. Warner Bros. Pictures, 224 F.2d 824, 826-27 (2d Cir. 1955), a definite trend now exists towards a rebuttable presumption. See, e.g., Novo Terapeutisk Lab. A/S v. Baxter Travenol Labs., Inc., 607 F.2d 186, 197 (7th Cir. 1979) (en banc); Akerly v. Red Barn Sys., Inc., 551 F.2d 539, 543-44 (3d Cir. 1977); Gas-A-Tron v. Union Oil Co., 534 F.2d 1322, 1325 (9th Cir.), cert. denied, 429 U.S. 861 (1976); Silver Chrysler Plymouth, Inc. v. Chrysler Motors Corp., 518 F.2d 751, 754 (2d Cir. 1975); City of Cleveland v. Cleveland Elec. Illum. Co., 440 F. Supp. 193, 209 
In Silver Chrysler Plymouth, Inc. v. Chrysler Motors Corp., ${ }^{25}$ a young lawyer who had worked for a law firm of moderately large size established his own firm and brought suit on behalf of a client against a client of his former employer. The Court of Appeals for the Second Gircuit, upholding the district court's refusal to disqualify the young lawyer, took note of the former law firm's size and the rapid turnover of its young associates, and observed:

[I]t would be absurd to conclude that immediately upon their entry on duty ... [ [associates of large law firms] become the recipients of knowledge as to the names of all the firm's clients, the contents of all files relating to such clients, and all the confidential disclosures by client officers or employees to any lawyer in the firm..$^{26}$

The court went on to hold that the presumption of imputed knowledge was rebuttable, and found "reason to differentiate for disqualification purposes between lawyers who become heavily involved in the facts of a particular matter and those who enter briefly on the periphery for a limited and specific purpose relating solely to legal questions." 27 A discriminating approach has also been followed in cases involving attorneys formerly employed by public agencies, in which concern for the employment prospects of former

(N.D. Ohio), aff'd mem., 573 F.2d 1310 (6th Cir. 1977), cert. denied, 435 U.S. 996 (1978); Fred Weber, Inc. v. Shell Oil Co., 432 F. Supp. 694, 697 (E.D. Mo.), aff'd on other grounds, 566 F.2d 602 (8th Cir. 1977), cert. denied, 436 U.S. 905 (1978), overruled in part on other grounds, In re Multi-Piece Rim Prods. Liability Litig., No. 79-1781 (8th Cir. Jan. 7, 1980) (en banc); Redd v. Shell Oil Co., [1974-2] Trade Cas. T75,392, at 98,278 (D. Utah 1974), rev'd in part on other grounds, 518 F.2d 311 (10th Cir. 1975). This Comment will refer to this presumption as the presumption of imputed knowledge, even though the same term could be applied to the first presumption described above.

A third presumption concerns what some courts have called a double imputation: the presumption that the knowledge of confidences ascribed to an individual lawyer by means of the presumption of imputed knowledge is shared with all the other lawyers in his or her firm. In reality, of course, this imputation is tripleknowledge of confidences is first imputed to the attorney representing the client, then to associated lawyers in his or her firm, and then again to lawyers who become associated with those associated lawyers. Not surprisingly, the courts have refused to countenance such double (or triple) imputation and have denied the existence of this presumption. See, e.g., Arkansas v. Dean Food Prods. Co., 605 F.2d 380, 386-87 (8th Cir. 1979), overruled in part on other grounds, In re Multi-Piece Rim Prods. Liability Litig., No. 79-1781 (8th Cir. Jan. 7, 1980) (en banc); American Can Co. v. Citrus Feed Co., 436 F.2d 1125, 1129 (5th Cir. 1971).

25518 F.2d 751 (2d Cir. 1975). See generally Note, The Second Circuit and Attorney Disqualification-Silver Chrysler Steers in a New Direction, 44 FORDHAM L. REv. 130 (1975).

26518 F.2d at $753-54$.

27 Id. 756. 
government attorneys and the government's ability to attract legal talent have played an important role. ${ }^{28}$

Once it is accepted that the presumption of imputed knowledge is rebuttable, the Chinese wall defense to firm disqualification begins to have meaning. An effective Chinese wall would serve to prevent the flow of information from the attorney or attorneys with knowledge of the former client's confidences and secrets to the rest of the attorneys in the firm. If walls were accepted as defenses, they could be employed to rebut the presumption of imputed knowledge and thereby to restrict the scope of the disqualification to the walled-off attorneys.

When adverse representations are undertaken concurrently, the "substantial relationship" test is not controlling, and the appropriateness of disqualification must be measured against "the duty of undivided loyalty which an attorney owes to each of his clients." 29 The danger of misuse of client confidences may also be present, but the court's attention in these cases will likely be riveted on the more compelling grounds provided by Canon 5 and the ancient maxim that "no man can serve two masters." 30 Indeed, it has been held that concurrent adverse representations are "prima facie improper." 31 Thus, although Chinese wall defenses have been raised in concurrent representation cases, ${ }^{32}$ the effort is not likely to be successful-even if the courts were to accept the defense as rebutting the presumption of imputed knowledge, the prob-

28 E.g., Kesselhaut v. United States, 555 F.2d 791, 793-94 (Ct. Cl. 1977) (en banc); Armstrong v. McAlpin, 461 F. Supp. 622, 624-26 (S.D.N.Y. 1978), rev'd, 606 F.2d 28 (2d Cir. 1979), rehearing en banc granted, No. 79-7042 (Dec. 12, 1979); United States v. Standard Oil Co., 136 F. Supp. 345, 363-64 (S.D.N.Y. 1955).

Government attorneys and their associates in the private sector may be liable to criminal sanctions for unethical conduct. See, e.g., 18 U.S.C.A. \$207 (Supp. 1979), as amended by Act of June 22, 1979, Pub. L. No. 96-28, 93 Stat. 76.

29 Cinema 5, Ltd. v. Cinerama, Inc., 528 F.2d 1384, 1386 (2d Cir. 1976); accord, e.g., Silver Chrysler Plymouth, Inc. v. Chrysler Motors Corp., 518 F.2d 751, 754 (2d Cir. 1975) (quoting Ceramco, Inc. v. Lee Pharmaceuticals, 510 F.2d 268, 271 (2d Cir. 1975)); T.C. Theatre Corp. v. Warner Bros. Pictures, 113 F. Supp. 265, 268 (S.D.N.Y. 1953); see Work Product, supra note 11, at 1614-17.

30 Matthew 6:24. E.g., Fund of Funds, Ltd. v. Arthur Andersen \& Co., 567 F.2d 225 (2d Cir. 1977); see text accompanying notes 43-65 infra.

The court will probably focus on Canon 5 because it will more likely be dispositive; the bar against serving two masters prevents concurrent, adverse representation even when the two matters are so unrelated as to present no danger of misuse of confidences. See IBM Corp. v. Levin, 579 F.2d 271, 280 (3d Cir. 1978); Work Product, supra note 11, at 1615-16.

31 Cinema 5, Ltd. v. Cinerama, Inc., 528 F.2d 1384, 1387 (2d Cir. 1976).

32 E.g., Westinghouse Elec. Corp. v. Kerr-McGee Corp., 580 F.2d 1311 (7th Cir.), cert. denied, 439 U.S. 955 (1978); Fund of Funds, Ltd. v. Arthur Andersen \& Co., 567 F.2d 225 (2d Cir. 1977). 
lem of dual loyalties would remain. Although conflicting representations could be conducted by different attorneys in the same firm, every attorney in the firm would nevertheless have an economic interest in the success of both representations. ${ }^{33}$ Whatever the effectiveness of Chinese walls in impeding the flow of confidential information, it cannot seriously be maintained that such information barriers are capable of curing conflicts of interest arising from a firm's divided loyalties. ${ }^{34}$

Whether successive or concurrent, adverse representations are likely also to run up against Canon 9's mandate to avoid even the appearance of impropriety. Although broad in scope, that requirement's main thrust is to obligate a lawyer to "promote public confidence" in the American legal system "and in the legal profession." 35 No matter how effective, Chinese walls are not likely to foster public confidence because the details of a law firm's efforts to avoid disqualification will doubtless make but a small impression upon public awareness. ${ }^{36}$ Thus, even if a firm succeeds in comply-

33 This holds true even for salaried associates and for firms not organized on a partnership basis because it may fairly be assumed that salaried employees, like partners, have an economic stake in the financial success of the employing organization.

34 One might argue that a wall barring attorneys working on case $A$ from receiving any remuneration from adverse case $B$, and vice-versa, effectively resolves the problem of divided loyalties. The effectiveness of such an arrangement has been denied by at least one court, albeit in a slightly different context. Armstrong v. McAlpin, 606 F.2d 28, 34 ( $2 \mathrm{~d}$ Cir. 1979), rehearing en banc granted, No. 79-7042 (Dec. 12, 1979) (former government attorney case). Even if the fees attributable to the adverse case could effectively be diverted, the long-range economic interests of the attorneys are too closely allied with those of the firm to resolve doubts about dual loyalties.

Some commentators have argued for narrow exceptions to the ban on concurrent, adverse representations, e.g., in uncontested divorce actions and in representation of the indigent by legal aid societies. See Aronson, supra note 9; Note, Simultaneous Representation: Transaction Resolution in the Adversary System, 28 CASE W. Res. L. Rev. 86 (1977); note 165 infra. Although it is conceivable that Chinese walls could play a role in these special situations, further exploration of them is beyond the scope of this Comment. For the sake of simplicity, the futility of the Chinese wall defense in cases of concurrent representation will be assumed.

35 EC 9-1. See, e.g., General Motors Corp. v. City of New York, 501 F.2d 639, 649 (2d Cir. 1974); Work Product, supra note 11, at 1617-19.

36 See, e.g., Aronson, supra note 9, at 848; Insulation or Disqualification, supra note 9 , at 417-18; Business as Usual, supra note 9, at 1553, 1566-68; 30 OKLA. L. Rev. 365, 373-74 (1977); of. Armstrong v. McAlpin, 606 F.2d 28, 34 (2d Cir. 1979), rehearing en banc granted, No. 79-7042 (Dec. 12, 1979) (casual observers would most likely be unaware of arrangements aimed at financially insulating disqualified attorney).

Many authorities that approve screening in Canon 9 cases do not focus on public awareness. See, e.g., id. 33; Kesselhaut v. United States, 555 F.2d 791, 793 (Ct. Cl. 1977) (en banc); ABA OpInoN 342, supra note 6, reprinted in 62 A.B.A.J. 517, 520-21 (1976); Comomititer on Professional and Judiclal Ethics, Ass' OF THE BAR OF THE CITY OF NEW YORK, OpInIONS, No. 889 (1976) [hereinafter cited as NYC BAR OpINION 889] reprinted in 31 Record 552, 566-71 (1976); 
ing with the letter of Canon 4 by erecting a wall, Canon 9's concern with the spirit of legal ethics must still be reckoned with. To the extent, then, that a violation of Canon 9 , without more, warrants disqualification, the Chinese wall defense will fail.

Recently, however, Judge Feinberg, writing for a panel of the Court of Appeals for the Second Circuit in Board of Education $v$. Nyquist, ${ }^{37}$ held that "unless an attorney's conduct tends to 'taint the underlying trial," " a mere "appearance of impropriety is simply too slender a reed on which to rest a disqualification order except in the rarest cases." 38 If Judge Feinberg's sensible view prevails, ${ }^{39}$ then Chinese wall defenses to charges of combined Canon 4 and Canon 9 violations may yet succeed, even though the wall is relevant primarily to the Canon 4 problem of misuse of confidences.

It should be noted that courts often analyze motions for disqualification of former government attorneys solely under Canon 9 because, technically speaking, no Ganon 4 violation exists. ${ }^{40}$ To the extent that these cases are concerned with the possible misuse of confidential information acquired while in the government's employ, they involve an impropriety that may "taint the underlying trial" and that is therefore more than just "apparent." Except for the lack of a former attorney-client relationship between the exgovernment attorney and the party moving for disqualification, such cases are essentially similar to cases involving Canon 4 viola-

Petition and Memorandum in Support of Petition of the Board of Governors of the District of Columbia Bar for Amendment of the Provisions Implementing Canon 9, Submitted to the District of Columbia Court of Appeals (Feb. 9, 1979), reprinted in Final Revolving Door Proposal, Distruct LAw., April/May, 1979, at 47 [hereinafter cited as Revolving Door Proposal].

37590 F.2d 1241 (2d Cir. 1979).

38 Id. 1246, 1247 (quoting in part W.T. Grant Co. v. Haines, 531 F.2d 671, 678 (2d Cir. 1976)).

39 The Nyquist position has been adopted or approvingly cited in the following: United States v. Birdman, 602 F.2d 547, 559-60 (3d Cir. 1979), cert. denied, 48 U.S.L.W. 3451 (1980) (indictment not dismissed although government attorney violated DR 5-102 by acting as both witness and advocate before grand jury); Emm Ess Metals Co. v. Triumph Alloys Int'l, Inc., [1979-1] Trade Cas. If 62,680 (S.D.N.Y. 1979) (corporation's former general counsel may represent party suing corporation absent Canon 4 violation); Kerry Coal Co. v. United Mine Workers, 470 F. Supp. 1032, 1035-37 (W.D. Pa. 1979); In re Airport Car Rental Antitrust litig., 470 F. Supp. 495, 502 n.5 (N.D. Cal. 1979); Danziger v. Compagnie Nationale Air France, No. 77 Civ. 1335 (S.D.N.Y. Apr. 18, 1979); Society for Good Will to Retarded Children, Inc. v. Carey, 466 F. Supp. 722, 724-25 (E.D.N.Y. 1979).

Although no reported cases have explicitly disapproved Nyquist, the decision in Armstrong v. McAlpin, 606 F.2d 28 (2d Cir. 1979), rehearing en banc granted, No. 79-7042 (Dec. 12, 1979), decided by a different panel of the same court of appeals, appears to contradict it, in substance, if not in form. See text accompanying notes 78-102 infra.

40 See note 18 supra. 
tions, and the Nyquist reservations about disqualification based solely on apparent impropriety do not apply. ${ }^{41}$

This briefest of outlines of disqualification law has attempted to identify those ethical violations against which the Chinese wall defense to firm disqualification might conceivably be successful. To summarize: Chinese walls are intended to prevent the flow of confidential information. If effective, a question to be taken up in part III, Chinese walls could serve as defenses to violations of Canon 4 's strictures against the disclosure or misuse of confidences in successive representation cases, and to similar offenses under Canon 9 involving ex-government attorneys. But Chinese walls offer no cure to a firm's Canon 5 problems in concurrent representation cases or to the broad range of apparent improprieties dealt with under Canon 9.

\section{The Current Legal Status of the \\ Chinese Wall Defense.}

Federal appellate courts have ruled on the Chinese wall defense to firm disqualification in only four cases, two involving concurrent representation of adverse clients and two involving successive representations by attorneys formerly employed by the federal government. A review of the facts and conclusions in these cases will clarify the present legal status of the Chinese wall defense. ${ }^{42}$

\section{A. Concurrent Representation Cases}

The two courts of appeals that have commented on Chinese walls in concurrent representation cases have adopted a similar stance. In Fund of Funds, Ltd. v. Arthur Andersen \& Co.43 and Westinghouse Electric Corp. v. Kerr-McGee Corp.,4 the wall defense met with sweeping and peremptory rejection. Although the facts in Fund of Funds were complex, it suffices to say that a law

41 See Board of Educ. v. Nyquist, 590 F.2d 1241, 1247-48 n.1 (2d Cir. 1979) (Mansfield, J., concurring).

42 But these cases may have no effect on the acceptance of walls in other contexts. For example, several agencies endorse screening procedures. . E.g., 17 C.F.R. $\$ 200.735-8(\mathrm{e})$ (1979) (SEC); 31 C.F.R. $\$ 10.26(\mathrm{c})$ (1978) (IRS); 46 C.F.R. $\$ 502.32$ (c) (1978) (Fed. Maritime Comm'n). For a general discussion of one of these regulations, see Chief Counsel's Advisory Committee on Rules of Professional Conduct, Final Report to the Hon. Meade Whitaker, Chief Counsel, 41 Fed. Reg. 41,106, 41,108-18 (1976).

43567 F.2d 225 (2d Cir. 1977).

44580 F.2d 1311 (7th Cir.), cert. denied, 439 U.S. 955 (1978). See Note, Westinghouse Electric Corp. v. Kerr-McGee Corp.: Attorney Disqualification for Conflict of Interest, 10 Lox. CFI. L.J. 271 (1979); 28 EMORY L.J. 215 (1979). 
firm sought to defend itself against accusations of simultaneous, adverse representations by arguing that a Chinese wall built between its attorneys working for the adverse clients prevented any confidential information from passing hands. ${ }^{45}$ The trial judge, finding a breach in the wall, curtly replied, "the Court finds that such a 'Chinese Wall' cannot be built within a single law firm." 46 The Second Circuit added in a footnote: "We incline to agree." $4 \pi$ Significantly, however, the appellate court also noted that contemporaneous, adverse representations constitute a breach of a client's "absolute right to the firm's undivided loyalty." 48

In Westinghouse Electric Corp. v. Kerr-McGee Corp., ${ }^{49}$ Westinghouse brought an antitrust action against a group of uranium producers, including three oil companies. ${ }^{50}$ Westinghouse's lead attorney for the uranium matter was the Chicago firm Kirkland \&

45567 F.2d at 229 n.10.

46 Fund of Funds, Ltd. v. Arthur Andersen \& Co., 435 F. Supp. 84, 96 (S.D. N.Y.), rev'd in part on other grounds, 567 F.2d 225 ( $2 \mathrm{~d}$ Cir. 1977).

47567 F.2d at 229 n.10.

48 Id. 233 (citing Cinema 5, Ltd. v. Cinerama, Inc., 528 F.2d 1384, 1386 (2d Cir. 1976)).

In greater detail, the facts in Fund of Funds were as follows. A mutual fund retained Morgan, Lewis \& Bockius (Morgan) as counsel in a suit against all but one of the principals in an allegedly fraudulent securities transaction. The one principal not sued was the fund's auditor, Arthur Andersen \& Co. (Andersen), whom Morgan had served as regional counsel for many years. In a separate action in which Morgan took no official part, the fund, represented only by the law firm of Milgrim, Thomajan \& Jacobs (Milgrim), sued Andersen for its role in the alleged fraud.

Andersen moved to disqualify Milgrim on the grounds that it was acting as Morgan's alter ego, and that Morgan, had it been the counsel of record, would clearly have been disqualified because of its long-standing representation of Andersen as regional counsel. The trial judge, in order to rule on the disqualification of Milgrim, found it necessary to rule first on the question whether Morgan would have been disqualified if it had represented the fund in the action against Andersen. 435 F. Supp. at 94 . Although Morgan was not represented in the disqualification proceeding and submitted no briefs, the trial judge read the deposition testimony of the Morgan attorneys as taking the position that the construction of a Chinese wall had prevented the disclosure of any confidential information. Id. $96 \& \mathbf{n} .45$. The district court, denying the possibility of a Chinese wall and finding that the two groups of Morgan attorneys were not in fact separated, ruled that Morgan would have been disqualified from bringing the suit against Andersen. It went on, however, to hold that Milgrim's contacts with Morgan were not sufficient to disqualify Milgrim as well. Id. 98. The court of appeals agreed with the lower court's view as to Morgan but also found sufficient cause to disqualify Milgrim. 567 F.2d at 227.

49580 F.2d 1311 (7th Cir.), cert. denied, 439 U.S. 955 (1978).

50 The three oil companies were Gulf Oil, Kerr-McGee, and Getty Oil. The case in the district court was Westinghouse Elec. Corp. v. Rio Algom Ltd., 448 F. Supp. 1284 (N.D. Ill. 1978). Another appeal from that decision was decided by the Seventh Circuit under the name Westinghouse Elec. Corp. v. Gulf Oil Corp., 588 F.2d 221 (7th Cir. 1978). 
Ellis.51 The oil companies were members of a petroleum trade association, which had retained Kirkland's Washington, D.C. office to compile a legislative report as part of a lobbying effort. Pursuant to this representation, Kirkland's Washington branch received from the oil companies confidential data pertinent to the antitrust suit. ${ }^{52}$

The oil companies moved to have Kirkland disqualified. Kirkland responded, in part, that it had built a Chinese wall between its Chicago attorneys working for Westinghouse and its Washington attorneys working for the trade association..$^{53}$ The district court found that Kirkland's work for the trade association did not create an attorney-client relationship with the individual member companies and thus perceived no violations of Canons 4 and 5.54 Taking note of Kirkland's large size, the use of separate teams of attorneys separated geographically as well as organizationally, the absence of actual disclosure, and recent decisions undermining the traditional presumption of imputed knowledge, ${ }^{55}$ the district court refused to disqualify the firm, and found the possibility of improper professional conduct "fairly remote." 56

The Seventh Circuit disagreed. It found an attorney-client relationship and thus ruled that Canons 4 and 5 , as well as Canon 9, were applicable. ${ }^{57}$ Pointing to a "breach" in the wall, the court added that it did "not recognize the wall theory as modifying the presumption that actual knowledge of one or more lawyers in a firm is imputed to each member of that firm." 58 Addressing the relevance of law-firm size, the court of appeals saw "no basis for creating separate disqualification rules for large firms even though

51 Kirkland \& Ellis is a Chicago firm with a branch in Washington, D.C. In 1977, Kirkland had 208 attorneys and was the tenth largest law firm in the country. Cantor, supra note 1 , at 216.

52580 F.2d at 1313-16, 1321.

53 Id. 1321.

54 Westinghouse Elec. Corp. v. Rio Algom Ltd., 448 F. Supp. 1284, 1303 (N.D. IIl.), rev. sub nom., Westinghouse Elec. Corp. v. Kerr-McGee Corp., 580 F.2d 1311 (7th Cir.), cert. denied, 439 U.S. 955 (1978).

55448 F. Supp. at 1304-05. The district court quoted from Silver Chrysler Plymouth, Inc. v. Chrysler Motors Corp., 370 F. Supp. 581, 588 (S.D.N.Y. 1973), affd, 518 F.2d 751 (2d Cir. 1975), and City of Cleveland v. Cleveland Elec. Illum. Co., 440 F. Supp. 193, 211 (N.D. Ohio), aff'd mem., 573 F.2d 1310 (6th Cir. 1977), cert. denied, 435 U.S. 996 (1978).

56448 F. Supp. at 1305.

57580 F.2d at 1321.

$58 \mathrm{Id}$. Judge Fairchild did not believe Kirkland was raising the Chinese wall defense on appeal. He noted that had Kirkland shown that the Washington and Chicago groups were effectively insulated from each other, "imputation of knowledge to all partners would be eliminated from consideration and a different result may have been appropriate." Id. n.28. 
the burden of complying with ethical considerations will naturally fall more heavily upon their shoulders." 59 Although the appellate court's discussion focused primarily on the Canon 4 problem, it briefly mentioned as a factor in its decision the Canon 5 implications of Kirkland's simultaneous, adverse representations. ${ }^{60}$

What significance do the decisions in Fund of Funds and Westinghouse have for the future of the Chinese wall defense? The courts' laconic remarks surely demonstrate a judicial hostility to screening devices in concurrent representation cases, but they do not spell the doom of Chinese walls. Even granting that the courts reached correct results and were partly justified in their skepticism regarding the potential effectiveness of Chinese walls, a more discriminating analysis is nevertheless required.

Perhaps the chief distinguishing feature of these cases is that they both involve contemporaneous, conflicting representations. According to the analysis presented in part I of this Comment, ${ }^{61}$ Chinese walls cannot combat dual-loyalty problems, and it is thus not surprising that courts should find the wall defense inadequate in cases presenting possible Canon 5 violations. But that inadequacy does not undercut the validity of Chinese walls in successive representation cases in which Ganon 5 complications are absent. As one court, distinguishing Fund of Funds, observed: "Rejection of screening as a device to prevent exchange of information within a law firm between attorneys with conflicting interests is not necessarily a rejection of screening in all circumstances." 62

The opinion of the court of appeals in Fund of Funds, which rested its judgment as to disqualification solely on the Canon 5 issue, readily lends itself to this distinction. Westinghouse, however, is not so easily distinguished. Had the Westinghouse court followed the lead of other courts faced with concurrent, adverse representations, ${ }^{63}$ it would have focused on the dual-loyalty problem and found a clear basis for disqualification in Canon 5. But the court in Westinghouse chose instead to concentrate, albeit in a somewhat muddled fashion, on the Canon 4 aspect. Nevertheless, one may still distinguish concurrent from successive representations in terms of Canon 4's purposes, even absent Canon 5 overtones.

59 Id. 1321.

60 Id. 1322.

61 See text accompanying notes 29-34 supra.

62 Armstrong v. McAlpin, 606 F.2d 28, 32 (2d Cir. 1979), rehearing en banc granted, No. 79-7042 (Dec. 12, 1979).

63 In addition to Fund of Funds, see, e.g., Cinema 5, Ltd. v. Cinerama, Inc., 528 F.2d 1384 (2d Cir. 1976). 
When two groups of attorneys within a single law firm are engaged in conflicting representations at one and the same time, there is a greater danger of disclosure of confidences than would exist if one of the representations took place in the past. In the first situation, the work is ongoing, papers are circulating, and the attorneys are actively going about their tasks, discussing, as people do, their everyday cares with their associates. By contrast, in the second situation, only one group of attorneys is actively engaged. The other representation is over and done with-documents relating to it are filed away, and the attorneys who worked on it are newly occupied with fresh business. Given the natural human concern with the present, it is less likely that attorneys who worked on the concluded litigation will inadvertently disclose confidential information acquired in the past. ${ }^{64}$ Thus, the Westinghouse court's announcement that it did not recognize Chinese walls as rebutting the presumption of imputed knowledge may be limited to the circumstances of that case: Chinese walls constructed between attorneys currently pursuing adverse representations. It need not be construed as rejecting the Chinese wall defense in successive representation cases. So limited, the Westinghouse view can be expected to play a minor role in the development of the Chinese wall defense because, as previously indicated, Canon 5 provides an ample alternative basis for disqualification in concurrent representation cases.

An additional reason justifies limiting the reach of Fund of Funds and Westinghouse, a reason that finds support in the axiom that courts should not paint with broad strokes when dealing with ethical principles. ${ }^{65}$ Because in both cases the courts found that the alleged walls had actually been breached, their comments on the validity of the Chinese wall defense were dicta. That defense, as advanced here, does not conclusively establish that confidential information has not been shared with other attorneys in the firm; it merely rebuts the presumption that such sharing has occurred. Evidence that disclosure has in fact taken place serves, in effect, to nullify the Chinese wall defense.

\section{B. Successive Representation Cases}

In the two Chinese wall cases involving law firms employing former government attorneys, the federal appellate courts reached

${ }^{64}$ Cf. Liebman, supra note 9 , at 1016 (time lag between representations diminishes value of confidential information).

65 United States v. Standard Oil Co., 136 F. Supp. 345, 367 (S.D.N.Y. 1955). 
opposite results. The Court of Claims, sitting en banc, vacated a disqualification order issued by a trial judge in Kesselhaut $v$. United States. ${ }^{66}$ In Armstrong $v$. McAlpin, ${ }^{67}$ a panel of the Court of Appeals for the Second Circuit disagreed with the trial court and found disqualification appropriate. Central to an understanding of both decisions is Formal Opinion 342 of the Committee on Ethics and Professional Responsibility of the American Bar Association. ${ }^{68}$

\section{Formal Opinion 342}

Prior to 1974, Disciplinary Rule 5-105 (D) prohibited affliated lawyers from accepting or continuing an employment if any one of them was required to decline or withdraw from employment under Disciplinary Rule 5-105, which concerns conflicts of interest. In that year, the rule was expanded to prohibit representation by a firm whenever one of its lawyers is forbidden by any disciplinary rule from engaging in a representation. ${ }^{69}$ On its face, the amended rule, combined with Disciplinary Rule 9-101 (B), which commands a lawyer not to "accept private employment in a matter in which he had substantial responsibility while he was a public employee," 70 would necessitate widespread disqualification of firms employing ex-government attorneys. ${ }^{71}$ In response to this problem, the ABA's Ethics Committee issued Formal Opinion 342. Concerned that an inflexible application of Disciplinary Rule 5-105 (D) would unduly limit the employment opportunities of government attorneys upon leaving government service and impair the ability of government to recruit talented young professionals, the Committee endorsed a screening procedure. In the Ethics Committee's view, Disciplinary (1978).

66555 F.2d 791 (Ct. Cl. 1977) (en banc), noted in 82 Drck. L. Rev. 625

67 606 F.2d 28 (2d Cir. 1979), rehearing en banc granted, No. 79-7042 (Dec. 12, 1979).

68 ABA OrInIon 342, supra note 6, reprinted in 62 A.B.A.J. 517 (1976). See generally Commentary, The Disqualification Dilemma: DR 5-105(D) of the Code of Professional Responsibility, 56 Neb. L. REv. 692 (1977). (1976).

69 ABA OpIñon 342 , supra note 6 , reprinted in 62 A.B.A.J. 517,517 \& n.1

70 DR 9-101(B).

71 Subsequent statements by the principals involved in the 1974 amendment to DR 5-105(D) indicate that the $\mathrm{ABA}$ did not anticipate the amendment's impact on the firms of former government attorneys. See Moskowitz, Can D.C. Lawyers Cut the Ties That Bind?, Jurus Doctor, Sept., 1976, at 34.

Recently, Professor Sutton, who served as Reporter for the ABA committee that wrote the Code of Professional Responsibility, revealed that the Code's disciplinary rules, including DR 5-105, were drafted for use in disciplinary proceedings and were never intended to be used as rules governing disqualification motions. Sutton, How Vulnerable Is the Code of Professional Responsibility?, 57 N.C. L. Rev. 497, 514-16 (1979). 
Rule 5-105 (D) should not apply to the firm, partners, or associates of a disqualified lawyer who has been screened "to the satisfaction of the government agency concerned from participation in the work and compensation of the firm on any matter over which as a public .employee he had substantial responsibility." 72

\section{Kesselhaut v. United States}

The spirit, if not the letter, of Formal Opinion 342 was adopted by the Court of Claims in Kesselhaut $v$. United States. ${ }^{73}$ The Kesselhaut law firm sued to recover fees earned in a prior representation of the Federal Housing Administration (FHA). To represent it in this fee-recovery suit, Kesselhaut retained the firm of Krooth \& Altman. One of Krooth's attorneys, Adolphus Prothro, had been general counsel of the FHA while that agency had been Kesselhaut's client. Accordingly, Protho was personally disqualified from representing Kesselhaut in its action against the government. Under amended Disciplinary Rule 5-105(D), it seemed as if the entire Krooth firm should also be disqualified, and the trial judge so held. ${ }^{74}$

The Court of Claims, sitting en banc, found that Prothro had been effectively isolated from his firm's handling of the case, and that, in addition, the firm had later erected a Chinese wall. ${ }^{75}$ Concerned that every former government attorney would infect all the members of any firm he or she joined and "take on the status of a Typhoid Mary," 76 the court relied on the reasoning behind Formal Opinion 342 to hold that disqualification of the entire Krooth firm was not justified. In one material respect, however, the court went beyond the ABA Ethics Committee's stance: although Formal Opinion 342 contemplated that the government agency in question would exercise a veto over the validity of any screening procedure, the Kesselhaut court upheld Krooth's Chinese wall despite the gov-

72 ABA OpInIoN 342, supra note 6, reprinted in 62 A.B.A.J. 517, 521 (1976). See also NYC BAR OpInoN 889, supra note 36, reprinted in 31 Record 552 (1976); Revolving Door Proposal, supra note 36, at 58.

73555 F.2d 791 (Ct. Cl. 1977) (en banc).

74 Id. 792.

75 Id. 793. The basis for the wall consisted of a memo to the firm's attorneys, providing that Prothro is

to continue to have no connection with the case, all other attorneys are not to discuss it with him and are to prevent any case documents from reaching him, the files are to be kept in a locked file cabinet, the keys . . . issued to other attorneys, clerks, and secretaries, only on a "need to know" basis.

Id.

$76 I d$. 
ernment's opposition. The court reasoned that it had a "nondelegable responsibility" to maintain ethical standards in the cases before it and could not allow the parties "to debase the matter into another phase of adversary tactics." 77

\section{Armstrong v. McAlpin}

The Chinese wall defense has been litigated more fully in Armstrong v. McAlpin ${ }^{78}$ than in any other reported federal case, and the recent grant of a rehearing en banc by the Second Circuit holds the promise of a major ruling on the status of Chinese walls in former government attorney cases. ${ }^{79}$ As Assistant Director of the Division of Enforcement of the Securities and Exchange Commission (SEC), Theodore Altman had helped supervise an investigation of McAlpin and others. Upon leaving the SEC in 1975, Altman joined the law firm of Gordon, Hurwitz, Butowsky, Baker, Weitzen \& Shalov (Gordon). Armstrong, a court-appointed receiver, later retained the Gordon frrm to serve as litigation counsel in a securities fraud derivative suit against McAlpin and other defendants, an

77 Id. 794. Accord, NYC BAR OpINION 889, supra note 36 , reprinted in 31 Recond 552, 566 (1976); see also Revolving Door Proposal, supra note 36, at 56-58.

78461 F. Supp. 622 (S.D.N.Y. 1978), rev'd, 606 F.2d 28 (2d Cir. 1979), rehearing en banc granted, No. 79-7042 (Dec. 12, 1979).

79 In granting rehearing en banc, the Second Circuit requested the parties to brief the question whether an order granting or denying disqualification is appealable. Armstrong v. McAlpin, No. 79-7042 (2d Cir., Dec. 12, 1979) (order granting rehearing en banc). The Second Circuit now follows the majority rule that orders denying, as well as orders granting, disqualification are appealable. Silver Chrysler Plymouth, Inc. v. Chrysler Motors Corp., 496 F.2d 800 (2d Cir. 1974) (en banc); accord, e.g., MacKethan v. Peat, Marwick, Mitchell \& Co., 557 F.2d 395, 396 (4th Cir. 1977) (on rehearing); Schloetter v. Railoc, Inc., 546 F.2d 706, 709 (7th Cir. 1976); Fullmer v. Harper, 517 F.2d 20, 21 (10th Cir. 1975); American Roller Co. v. Budinger, 513 F.2d 982, 983 (3d Cir. 1975); Tomlinson v. Florida Iron \& Metal, Inc., 291 F.2d 333, 334 (5th Cir. 1961). See generally Comment, The Appealability of Orders Denying Motions for Disqualification of Counsel in the Federal Courts, 45 U. CHI. L. Rev. 450 (1978) [hereinafter cited as Appealability]; see also Work Product, supra note 11, at 1631-32.

But as disqualification motions have proliferated and become an important, harassing litigation tactic, a growing minority of circuits has distinguished rulings denying disqualification from those granting it, and held the former non-appealable. In Re Multi-Piece Rim Prods. Liability Litig., No. 79-1781 (8th Cir. Jan. 7, 1980) (en banc) (prospective ruling); Melamed v. ITT Continental Baking Co., 592 F.2d 290, 295-96 (6th Cir. 1979) (prospective holding); Community Broadcasting, Inc. v. FCC, 546 F.2d 1022, 1026-28 (D.C. Cir. 1976). A rule against appealability has Iong prevailed in the Ninth Circuit. Cord v. Smith, 338 F.2d 516, 521-22 (9th Cir. 1964).

The Second Circuit has previously hinted at discontent with the Silver Chrysler rule. See, e.g., Board of Educ. v. Nyquist, 590 F.2d 1241, 1247 n.8 (2d Cir. 1979); Appealability, supra, at 451 n.5. Should the Second Circuit join this trend and follow the lead of the Sixth and Seventh Circuits in limiting the new rule to prospective application, it would still have to reach the merits of the disqualification issue posed by Armstrong. 
action which grew directly out of the SEC investigation. The Gordon firm, concluding that Altman was disqualified by virtue of his participation in the SEC investigation, sought to ward off disqualification of the entire firm by screening Altman from the firm's conduct of the suit in accordance with Formal Opinion 342. The SEC gave its approval to this arrangement, as did the trial judge who had appointed Armstrong. ${ }^{80}$

The defendants in the derivative suit moved to disqualify Gordon and argued that Altman's knowledge acquired in the SEC investigation must be imputed to all members of the firm. The district court reviewed Formal Opinion 342 and a similar opinion of the Association of the Bar of the City of New York, ${ }^{81}$ and on the basis of the walling procedures and other evidence found disqualification unnecessary. The court distinguished the Second Circuit's opinion in Fund of Funds as involving an issue of conflicting representations and expressed agreement with the Court of Claims's opinion in Kesselhaut. Attempts by the defendants to impeach the effectiveness of the procedures employed to screen Altman were rejected by the district court as factually incorrect. ${ }^{82}$

On appeal, a panel of the Court of Appeals for the Second Circuit, in an opinion by Judge Newman, reversed. ${ }^{83}$ Declining to formulate a general rule concerning the law firms of former government attorneys who are disqualified under Disciplinary Rule 9101 (B), the court focused on the danger that government attorneys will misuse their authority in order to enhance their prospects for private employment. Two relevant factors affecting the scope of a disqualification were identified. First, whether the firm should be disqualified depends upon whether the "matter" for which the former government attorney once had "substantial responsibility" presents risks against which Disciplinary Rule 9-101 (B) was meant to guard. ${ }^{84}$ On this account, the court of appeals attempted to dis-

80461 F. Supp. at $623-24$. The trial court described the screening procedures as follows:

Altman is excluded from participation in the action, has no access to relevant files and derives no remuneration from funds obtained by the firm from prosecuting this action. No one at the firm is permitted to discuss the matter in his presence or allow him to view any document related to this litigation, and Altman has not imparted any information concerning Growth Fund to the firm.

Id. 624 .

81 NYC BAR OpINION 889, supra note 36, reprinted in 31 Record 552 (1976). 82461 F. Supp. at 626 n.5.

12, 1979).

83606 F.2d 28 (2d Cir. 1979), rehearing en banc granted, No. 79-7042 (Dec.

84 Id. 33. 
tinguish Kesselhaut as a case in which the disqualified attorney's governmental duties were only tangentially related to the subject matter of the litigation and thus had offered him no opportunity for enhancing his employment prospects. Second, extension of disqualification to the law firm turns on the nature of the exgovernment attorney's former responsibilities-if the disqualified attorney's role was active and personal, then a substantial appearance of impropriety exists if the firm is permitted to continue the representation, and screening procedures would not suffice to overcome it; but if the attorney's role was merely formal or supervisory, then the appearance of impropriety is not so great and possibly susceptible to cure by appropriate screening measures. ${ }^{85}$

In the case before it, the court found as a matter of law that a Chinese wall, no matter how carefully observed, could not prevent disqualification:

A government attorney with direct, personal involvement in a matter involving enforcement of laws that are the basis for private causes of action must understand, and it must appear to the public, that there will be no possibility of financial reward if he succumbs to the temptation to shape the government action in the hope of enhancing private employment. ${ }^{86}$

Despite this strong language, Judge Newman was careful to narrow the scope of his opinion. Rejecting the defendants' contentions that Fund of Funds had settled the legal status of the Chinese wall defense once and for all, he instead limited that case to its context of contemporaneous, conflicting representations. ${ }^{57}$ Furthermore, although the parties and the court below focused on the issue whether Altman's knowledge of the McAlpin matter should be imputed to the rest of his firm, ${ }^{88}$ the court of appeals chose not to dispute the trial court's finding that Altman's knowledge in fact was not shared. That finding was significant because it necessarily presupposed that the presumption of imputed knowledge was rebuttable in former government attorney cases. ${ }^{89}$ By concentrating instead on the danger that government service might be used as a tool for enhancing private employment prospects, Judge Newman at least left open the possibility of a future ruling

$85 I d$.

86 Id. 34.

87 Id. 32.

88461 F. Supp. at $624-27$.

89 See text accompanying notes 22-28 supra. 
that the Chinese wall defense suffices to rebut the presumption of imputed knowledge.

However, narrowly drawn, the panel's opinion in Armstrong has shortcomings which may not be ignored. Chief among them is the failure to acknowledge the lessons of the Second Circuit's recent opinion in Board of Education v. Nyquist. ${ }^{90}$ In that case the court announced a rule that disqualification is only appropriate when the conduct in question "tends to 'taint the underlying trial" " 01 and suggested that other ethical violations could adequately be dealt with in separate disciplinary proceedings. Applying Nyquist to the circumstances of Armstrong, it is clear that the disqualification was not required to protect the underlying trial. The trial court found that the firm's continued representation would not prejudice the defendants, ${ }^{92}$ and the court of appeals, far from disputing that holding, candidly recognized that its disqualification of the Gordon firm was intended "as a prophylactic measure to guard against misuse of authority by government lawyers." 93

The Armstrong court's attempt to distinguish Nyquist does not hold up under scrutiny. The court first argued that Nyquist did "not inevitably preclude disqualification" 94 for violation of standards other than Canon 4 or 5 , and pointed to a footnote in Judge Mansfield's concurring opinion in Nyquist, in which he recognized that a former government attorney could be disqualified for violating Disciplinary Rule 9-101 (B). ${ }^{95}$ Judge Mansfield, however, clearly agreed with the standard proposed in Judge Feinberg's opinion for the court in Nyquist; his footnote was appended to a sentence observing that an "appearance of impropriety" that affected the outcome of the trial would be rare indeed. ${ }^{96}$ The Armstrong court's reliance on the concurring opinion in Nyquist is therefore incorrect because nothing Judge Mansfield wrote may be taken as supporting the use of disqualification in private suits

90590 F.2d 1241 (2d Cir. 1979). See text accompanying notes 37-41 supra. 1976)).

91 Id. 1246 (quoting W.T. Grant Co. v. Haines, 531 F.2d 671, 678 (2d Cir.

92461 F. Supp. at 626.

93606 F.2d at 34 (footnote omitted).

94 Id. 32.

${ }^{95}$ Id. 32 \& n.3 (citing Board of Educ. v. Nyquist, 590 F.2d 1241, 1247 \& n.1 (2d Cir. 1979) (Mansfield, J., concurring)).

98590 F.2d at 1247 n.1. Citing a case that involved disqualification of an ex-government attorney, Judge Mansfield pointed out the risk in that case that confidential information acquired in government service might prejudice the outcome of the trial. 
purely as a prophylactic measure designed to foster ethics in government.

Similarly, the Armstrong panel's observation that Nyquist was "not at all concerned with the extent of a disqualification" 97 is hard to fathom. One would think that Nyquist's admonition that "courts should be quite hesitant to disqualify an attorney" 98 demands more stringent adherence when the issue reaches beyond disqualification of a single lawyer to the disqualification en masse of every lawyer in a firm.

Judge Newman's two-variable test for firm disqualification is likewise not without difficulty. Law firms are now instructed to ask: 'is the 'matter' for which the disqualified lawyer had 'substantial responsibility' the kind of matter where the risks against which DR 9-101 (B) guards are present?" 99 The short answer to this question would seem to be-if it is not that "kind" of matter, then the former government attorney should not be disqualified in the first place, and the question of the firm's disqualification should not even arise. This would-be variable is really a constant-in any case in which a former government attorney is disqualified, his or her firm would be too because the risks that Disciplinary Rule 9-101 (B) protects against would necessarily be present.

The court's attempt to distinguish Kesselhaut carries this illogic another step. ${ }^{100}$ To say that Kesselhaut involved no risk of enhancing private employment is not to distinguish it, but only to conjure up an issue that was not present in that case. The issue actually litigated and decided in Kesselhaut was whether the exgovernment attorney's knowledge of the matter should be imputed to the other members of his firm so as to disqualify them, the very same issue that was litigated in and decided by the district court in Armstrong.

The idea behind Armstrong's second proposed variablewhether the former government attorney's involvement in the matter was active and personal or merely formal and supervisoryseems somewhat confused. This variable seemingly concerns two distinct kinds of impropriety: ( 1 ) the danger that knowledge of confidential information gained while in government service will be used or disclosed; and (2) the danger that government employees will manipulate the matters before them to enhance future job pros-

97606 F.2d at 32 (emphasis in original).

98590 F.2d at 1246.

99606 F.2d at 33.

100 The Armstrong court, although not disapproving Kesselhaut, was careful to express "no opinion on that result." Id. 
pects. Although it is readily apparent how the first danger increases as a lawyer's participation in a matter becomes more active and personal, that danger played no part in the Armstrong scenario, as related by the trial court and confirmed by the court of appeals. ${ }^{101}$ Perhaps due to the lower court's finding of the lack of any such disclosure, the circuit court occupied itself with the second danger. Although the court seemed to think that formal, supervisory responsibility provides less opportunity for misuse of authority than active, personal involvement, that proposition is by no means an obvious one. On the contrary, one would expect that the higher up an attorney is situated on the supervisory ladder, the greater the power to manipulate. Active and personal involvement would ordinarily correlate with a subordinate position having little authority to misuse.

Despite Armstrong v. McAlpin's failures, one might still inquire whether the case was correctly decided. Altman's disqualification was not contested, and the only issue confronting the court was the firm's disqualification. Moreover, the court below had decided, and the court of appeals did not disagree, that Altman's special knowledge of the matter had not been shared with his colleagues in the Gordon firm. Did the danger that government attorneys other than Altman might misuse their authority compel disqualification of Altman's firm?

As a measure designed to deter government attorneys from using their authority to curry favor with future employers, disqualification of the Gordon firm in Armstrong because of Altman's active and personal involvement in a substantially related matter seems arbitrary and ineffective. Why disqualify the firm only in substantially related cases? Surely a firm knows when it hires a government lawyer that he or she will be disqualified in any matters in which he or she was actively and personally involved, and that in such cases, the firm, too, will run a high risk of disqualification. If government attorneys are willing to misuse their authority for private gain, it seems unlikely that they, or their future employers, will be deterred by the prospect of disqualification in a handful of representations. The only effective way to use disqualification to deter such misconduct would be to disqualify the firm in every case, that is, to ban government lawyers from moving into private practice.

The flimsiness of the deterrence rationale in Armstrong only underscores the extent to which the court of appeals rested its de- 
cision on the appearance-of-impropriety doctrine. Even though no actual impropriety took place, and even though disqualification could have but a miniscule deterrent effect on the future conduct of government lawyers, nevertheless, the court seems to have felt that the situation looked bad.

Disqualification is an excessive sanction for the appearance of a concededly nonexistent impropriety. A court concerned with the public's baseless perceptions of evil would be well-advised to follow Nyquist's advice to proceed cautiously. The public, after all, might be equally, if not more concerned, over the use of disqualification as a litigation tactic resulting in hardships to innocent clients. In Armstrong, for example, the Gordon firm was not disqualified until three years after the complaint was filed. Moreover, if the public were inclined to think about the effect of disqualification on the government's ability to attract and retain competent professionals, it might also be unwilling to give judges the authority to enact into law their necessarily subjective appraisals of public opinion. Such considerations highlight the wisdom of Nyquist's teaching that the notion of "appearance of impropriety" is simply too vaporous to support a disqualification order, especially when compared to the concrete effects disqualification has on the client, the attorneys, the underlying litigation, and the judicial system. In light of the weighty policies, articulated in Kesselhaut, Formal Opinion 342, and elsewhere, against disqualification of the firms of former government attorneys, the Armstrong panel's hypersensitivity to ethical nuances must be rejected as unwarranted in the disqualification context. ${ }^{102}$

102 See, e.g., NYC BAR OpINIoN 889, supra note 36, reprinted in 31 RuEcoro 552 (1976); Kaufman, supra note 13; Comment, Conflicts of Interest and the Former Government Attorney, 65 GEo. L.J. 1025 (1977); Revolving Door Proposal, supra note 36 .

To allow disqualification based solely on the appearance of impropriety gives to appellate review a broader scope than would otherwise be available. It is well established that the district courts bear the primary responsibility for supervising the members of their bars and that their findings are reversible only for abuse of discretion. See, e.g., Hull v. Celanese Corp., 513 F.2d 568, 571 (2d Cir. 1975). In Armstrong, the facts as found by the district court showed no evidence of actual impropriety, and reversal for abuse of discretion would have been difficult to justify. That course would also have impugned the integrity of the attorneys involved, a step which courts in general are understandably reluctant to take. Measuring the acceptable level of improper appearances, however, lends itself to characterization as a legal question, one judge being as capable as another to decide what is good for the legal system. Thus the court of appeals in Armstrong was able to paint its reversal of the district court as flowing from disagreement over the applicable legal rule rather than from the lower court's abuse of discretion. Armstrong v. McAlpin, 606 F.2d 28, 34 n.7 (2d Cir. 1979), rehearing en banc granted, No. 79-7042 (Dec. 12, 1979). 


\section{Successive Representations and Former Private Attorneys}

To date, the attention of the bar and the courts in successive representation cases raising questions of firm disqualification has focused on the problem of the former government attorney. No recent Chinese wall cases have been reported in which the disqualified lawyer's contact with the matter in question grew out of his or her former private employment. ${ }^{103}$ In such a case, as in the former government attorney cases, Disciplinary Rule 5-105(D) would appear to create an absolute bar to continued representation by the firm. Yet here, too, there are persuasive reasons why a strict application of the rule should be avoided.

Once it is admitted that a Chinese wall can rebut the presumption of imputed knowledge in former government attorney cases, it becomes difficult to insist that the presumption is irrebuttable when the disqualified.attorney's previous employment was private and not public. To hold fast to such a proposition would logically require a belief that privately employed attorneys are inherently incapable of being effectively screened, as though they were less trustworthy or more voluble than their ex-government counterparts. $^{104}$ If former government attorneys can be screened effectively, it follows that former private attorneys can too. ${ }^{105}$

One might attempt to characterize the former government attorney exception as a clash between ethical precepts and public policy in which the government's practical need to hire qualified lawyers prevails. According to this view, the presumption of imputed knowledge remains irrebuttable, but the strong public policy favoring job mobility of ex-government attorneys overrides it. The former government attorney cases could thus be seen as a narrow and unique exception to the traditional firm-disqualification rule and Disciplinary Rule 5-105 (D).

103 In W.E. Bassett Co. v. H.C. Cook Co., 201 F. Supp. 821 (D. Conn.), aff'd per curiam, 302 F.2d 268 (2d Cir. 1962), the attorney representing Bassett in an ongoing litigation against Cook joined a firm that had formerly represented Cook. Although the firm built a Chinese wall around itself to allow the new attorney to continue the representation, the court disqualified the attorney. Given these unusual facts, it is not surprising that the court, in this early case, found the Chinese wall defense inadequate. See text accompanying notes 156-65 infra.

104 Although Americans have traditionally held public servants in high regard, it now appears all too clear that even Supreme Court law clerks lack immunity to the temptations of gossip. See generally B. WoOdward \& S. Armstrong, The BRETHREN (1979).

105 There are, of course, policy considerations unique to government employment against which a wall may give little protection, such as the danger of the misuse of authority by government attorneys. It is the contention of this Comment, however, that such additional concerns do not in the ordinary case warrant disqualification of the firm. See text accompanying notes $37-41$ supra. 
The former government attorney cases and the opinions of the bar, however, indicate a contrary understanding. They recognize that the presumption of imputed knowledge is rebuttable. Moreover, these authorities cannot be said to favor a balancing approach that would overlook the commission of ethical violations out of an excessive concern for the government's personnel needs. Rather, they correctly perceive the firm-disqualification rule as serving a dual purpose: to prevent instances of actual impropriety and also to avoid the appearance of impropriety. Only the first of these may fairly be characterized as ethical; the second is more a matter of public policy. ${ }^{106}$ When no risk of actual impropriety is present, and disqualification of the firm would function solely to avoid improper appearances, it makes sense to take into account other, countervailing public policies. Thus, the court in Kesselhaut embarked on its discussion of policy considerations only after noting that "truly unethical conduct has not taken place and the matter is merely one of the superficial appearance of evil, which a knowledge of the facts will dissipate." ${ }^{107}$ And the ABA Ethics Committee, in Formal Opinion 342, conditioned the approval of screening procedures on the absence of any appearance of significant impropriety. ${ }^{108}$

The exception these authorities carve out from the firm-disqualification rule, therefore, is not in principle capable of limitation to former government attorney cases. Once it is recognized that, like Canon 9, the firm-disqualification rule is in part a prophylactic measure, not confined to protecting the underlying trial against taint, then the specific public policy on which one relies to defeat disqualification becomes less significant. The door is open to consideration of policies other than those present in the former government attorney cases.

The Second Circuit's landmark decision in Silver Chrysler Plymouth, Inc. v. Ghrysler Motors Corp.${ }^{109}$ provides strong support for this conclusion. Although none of the policies unique to the former government attorney cases were present in Silver Chrysler, the court of appeals thought another policy supported its decision: "[t]he importance of not unnecessarily constricting the careers of lawyers who started their practice of law at large firms simply on

106 See, e.g., Work Product, supra note 11, at 1617-19.

107 Kesselhaut v. United States, 555 F.2d 791, 793 (Ct. Cl. 1977) (en banc). 108 ABA OpINION 342, supra note 6, reprinted in 62 A.B.A.J. 517, 521 (1976). See also NYC BAR OpINXoN 889, supra note 36, reprinted in 31 Record 552 (1976). But see Revolving Door Proposal, supra note 36, at 57.

109518 F.2d 751 (2d Cir. 1975). 
the basis of their former association." 110 Significantly, the presumption of imputed knowledge was rebutted in Silver Chrysler even though the attorney's former law firm had made no efforts to shield him from gaining access to the confidences and secrets of its client. To suggest that the presumption may be so casually defeated in the Silver Chrysler context while maintaining that it is irrebuttable when a law firm, cognizant that its procedures will be scrutinized by a trial court, makes every effort to wall off its tainted members, would be absurd.

Support for a pragmatic approach to firm disqualification is brewing in the American Bar Association itself. In its latest draft of the Model Rules of Professional Conduct, the ABA Commission on Evaluation of Professional Standards discards the irrebuttable presumption of imputed knowledge in section 7.1 (b) (1) and favors instead a case-by-case approach that turns on the existence of a "significant risk" of disclosure or improper use of client confidences. ${ }^{111}$ The Commission's accompanying comment recognizes that courts have held the presumption of shared confidences to be conclusive, but finds that presumption "unrealistic when the firms are large or where the clients are represented only for limited purposes." 112 Although the comment stops short of an explicit endorsement of the Chinese wall defense, it may be described as an invitation to try it; in the case of a lawyer having "access to the files of only a limited number of clients" and participating "in discussion of the affairs of no other clients," it states that "in the absence of information to the contrary, it should be inferred that such a lawyer in fact is privy to the confidences of the clients he has served but not those of other clients." 113 Factors cited as bearing on the determination of the likelihood of actual access are the lawyer's professional experience, the "division of actual respon-

110 Id. 754. Judge Weinstein's scholarly district court opinion in Silver Chrysler found substantial antitrust implications in ethical restrictions on the job mobility of young associates in large law firms. $370 \mathrm{~F}$. Supp. at 591. Although the court of appeals expressly took exception to those findings, 518 F.2d at 757 n.9, subsequent developments in the case law appear to shed new light on the issue. See National Soc'y of Professional Eng'rs v. United States, 435 U.S. 679 (1978); Goldfarb v. Virginia State Bar, 421 U.S. 773 (1975).

The anticompetitive effects of the Code have been the subject of much recent critical commentary. See, e.g., J. AUERBACH, UNEQUAT JUSTICE 40-73 (1976); J. Limberman, Crisis at THE BAR 68-106 (1978); Francis \& Johnson, The Emperor's Old Clothes: Piercing the Bar's Ethical Veil, 13 WnLAMETTE L.J. 221 (1977); Huber, Competition at the Bar and the Proposed Code of Professional Standards, 57 N.C. L. Rev. 559 (1979); Morgan, supra note 16.

111 MODEL RULES, supra note 17 , at $\$ 7.1(\mathrm{~b})(1)$.

112 Id. \$7.I, Comment, at 109 .

113 Id. 110. 
sibility for the matters involved," the firm's organizational structure, and the sensitivity and relevance of the information involved. ${ }^{114}$

In successive representation cases, the former government attorney exception, the Second Circuit's decisions in Nyquist and Silver Chrysler, and the ABA Commission's discussion draft of the Model Rules, suggest that the presumption of imputed knowledge should be deemed rebuttable, whether the disqualified lawyer's previous employment was private or public. Because that presumption is rebuttable, the Chinese wall defense should be treated no differently in former public than in former private attorney cases.

\section{The Effectrveness of Chinese Walls}

Whether courts should accept the Chinese wall defense as rebutting the presumption of imputed knowledge depends, in part, on an assessment of the effectiveness of screening procedures in stemming the disclosure within a law firm of the confidences and secrets of its clients. In part $I$, this Comment sought to examine, in preliminary fashion, the types of ethical violations against which Chinese walls might conceivably guard. ${ }^{115}$ Part II surveyed the developing case law on Chinese walls and related issues, and concluded that existing precedents support acceptance of the Chinese wall defense in successive representation cases. ${ }^{116}$ To date, however, no court has undertaken to form an empirical estimate of the effectiveness of walls. Even those courts that have condoned screening procedures have done so without considering whether walls are deserving of respect. Although the probable effectiveness of a particular Chinese wall must be considered by a court on the facts and circumstances peculiar to the case, ${ }^{117}$ part III is addressed to the more general inquiry whether Chinese walls can ever be sufficiently effective to warrant judicial attention. Part III attempts this task,

114 Id. A separate section provides that no lawyer in a firm "may accept" a representation that a former government attomey in the firm would be required to decline, id. $f 1.11$ (e), a rule apparently grounded in the risk of misuse of governmental authority. Id. Comment, at 37-38. Whether this section forecloses the Chinese wall defense to law-firm disqualification in the former government lawyer context is a matter of some difficulty. The use of the term "may" instead of "shall" indicates an area "in which the lawyer acts according to professional discretion." Id. Scope and Definitions, at 4. Furthermore, the ABA Commission's discussion draft warns against use of the Model Rules as "procedural weapons" in nondisciplinary proceedings, a caution which appears to include disqualification motions. Id. 5. Thus, the Model Rules do not mandate a strict rule of law-firm disqualification in former government attorney cases and could possibly be reconciled with the Nyquist approach as interpreted in this Comment.

116 See text accompanying notes 16-41 supra.

116 See text accompanying notes 42-114 supra.

117 See text accompanying notes 156-65 infra. 
first by examining the use of Chinese walls in financial institutions and then by comparing law-firm walls to their financial counterparts.

\section{A. Chinese Walls in Financial Institutions}

Securities firms and banks, plagued by conflict of interest problems analogous to those of law firms, routinely build Chinese walls to protect their clients. ${ }^{118}$ Given the legal profession's lack of experience with walls, the effectiveness of walling procedures in financial institutions merits examination.

Conflicts of interest arise in a securities firm because of its multiple functions, as investment banker on the one hand and as securities broker, dealer, and investment adviser on the other. ${ }^{119}$ In its capacity as investment banker, a securities firm has a duty to guard the confidentiality of financial secrets it receives from its customers. At the same time, however, the firm's broker-dealer or investment advising department may be making recommendations concerning the securities of these very same customers, and the investment management arm of the securities firm may be buying or selling those securities for accounts it manages. ${ }^{120}$ In the performance of these functions, the securities firm owes a conflicting duty under rule $10 \mathrm{~b}-5$ to disclose inside information or to refrain from using it in trading or recommending the securities in question. ${ }^{121}$

Like their counterparts in securities firms, commercial-bank employees also receive confidential information as investment bankers, direct lenders, and board members. ${ }^{122}$ Because banks also buy and sell securities, both on their own accounts and as trustees and

118 The experience of financial institutions with Chinese walls has engendered extensive commentary. E.g., Herman \& Safanda, The Commercial Bank Trust Department and the "Wall," 14 B.C. Indus. \& CoM. L. Rev. 21 (1972); Herzel \& Colling, The Chinese Wall and Conflicts of Interest in Banks, 34 Bus. LAw. 73 (1978) (and sources cited therein at 75 n.I); Huck, The Fatal Lure of the "Impermeable Chinese Wall," 94 BANKING L.J. 100 (1977); Hunsicker, Conflicts of Interest, Economic Distortions, and the Separation of Trust and Commercial Banking Functions, 50 S. CAI. L. REv. 611 (1977) (and sources cited therein at 634 n.126); Lipton \& Mazur, The Chinese Wall Solution to the Conflict Problems of Securities Firms, 50 N.Y.U. L. REv. 459 (1975) (and sources cited therein at 462 n.7); Méndez-Peñate, The Bank "Chinese Wall": Resolving and Contending with Conflicts of Duties, 93 Bankang L.J. 674 (1976); Yellon, Trust Investments: Problems Regarding Exchange of Information between the Trust Department and Other Departments within the Bank, 54 Crr. B. Rec. 405 (1973); Note, Conflicting Duties of Brokerage Firms, 88 Harv. L. Rev. 396 (1974).

119 Lipton \& Mazur, supra note 118, at 464-70.

120 Id. 464-66.

121 SEC v. Texas Gulf Sulphur Co., 401 F.2d 833, 848 (2d Cir. 1968) (en banc), cert. denied, 349 U.S. 976 (1969), 404 U.S. 1005 (1971); Cady, Roberts \& Co., 40 S.E.C. 907, 912 (1961); Lipton \& Mazur, supra note 118, at 465-66.

122 See Herman \& Safanda, supra note 118, at 22-26; Herzel \& Colling, supra note 118 , at $75-80$. 
investment managers, they encounter conflicts of interest substantially identical to those faced by securities firms. ${ }^{123}$

To prevent such conflicts from arising, financial institutions have developed structural, procedural, and educational methods for containing confidential information. Structurally, separate financial roles-investment banker, broker-dealer, trustee-have been assigned to distinct groups of employees, and this division of labor is reflected in discrete departments in almost every financial institution of appreciable size. Recently, these internal structural arrangements have even acquired legal status through incorporation, ${ }^{124}$ a trend one observer thinks may serve to reduce the probability of information leaks by creating a heightened sense of corporate identity. ${ }^{125}$

Organizational separation may be supplemented by physical separation, ${ }^{126}$ a practice intended to reduce the possibility that a department, either accidentally or in deliberate violation of company policy, will gain access to prohibited information. ${ }^{127}$ Physical separation, like incorporation, is also thought to increase the sense of departmental identity. ${ }^{128}$

123 See sources cited in note 122 supra.

Other banking conflicts of interest and legal problems arising from multiple functions are described in Herzel \& Colling, supra note 118, at 102-14; Hunsicker, supra note 118, at 619-30. One possible conflict that need not arise from performance of multiple functions is related to a possible duty to refrain from aiding takeovers of corporate borrowers. Whether such a duty exists and whether Chinese walls can prevent such a conflict are current controversial topics. See generally Washington Steel Corp. v. TW Corp., 602 F.2d 594 (3d Cir. 1979), noted in Case Comment, Bank Financing of Hostile Takeovers of Borrowers: Washington Steel Corp. v. TW Corp., 93 Harv. L. Rev. 440 (1979); Bid for McGraw Raises Questions on Bank's Role, N.Y. Times, Dec. 23, 1978, at D4, col. 1; Court's Bar on Chemical's Takeover Loan Holds Serious Implications for Big Banks, Wall St. J., Feb. 20, 1979, at 4, col. 2; see also As Charges Intensify. Strategy is Emerging in McGraw-Hill Battle, id., Jan. 29, 1979, at 11, col. 6; 23, col. 3 (American Express developing Chinese wall defense on behalf of its president, a director of the takeover target, McGraw-Hill).

124 Since 1970, banks have taken advantage of the Bank Holding Company Act Amendments of 1970, Pub. L. No. 91-607, Title I, $\$ 103(4), 84$ Stat. 1760 (codified at 12 U.S.C. $\$ 1843$ (c)(8) (1976)), by spinning off or acquiring corporations to perform functions not strictly part of commercial banking. See Hunsicker, supra note 118, at 615. Securities firms sometimes incorporate departments possessing a great potential for conflict, such as trust divisions and firm-run mutual funds. See Lipton \& Mazur, supra note 118, at 496.

125 See Hunsicker, supra note 118, at 618 n.32.

126 See Herzel \& Colling, supra note 118, at 91. A few large banks have even placed potentially conflicting departments in different buildings. Id.

127 See Hunsicker, supra note 118, at 615-16. But cf. Herzel \& Colling, supra note 118, at 115 ("Separation is also a poor solution because the same problem would remain in the separated trust department."). For other benefits of separation, see generally Hunsicker, supra note 118, at 614-19.

128 See Herman \& Safanda, supra note 118, at 43 ("Physical separation and profit center status reinforce the impetus toward autonomy."). 
Routine, internal procedures for the handling of confidential information constitute another screening method prevalent in financial institutions. At the heart of these procedures is restricted access to files. ${ }^{129}$ Thus, banks typically attempt to prohibit access by trust department personnel with investment responsibilities to files containing commercial credit information, ${ }^{130}$ and securities firms utilize equivalent procedures. ${ }^{131}$

A third ingredient in the construction of a Chinese wall is educational in nature. Although outside sanctions may apply to conduct that breaches a wall, ${ }^{132}$ some employees may not adequately be acquainted with the relevant legal standards. And if the firm's policy remains unspoken, even those employees who are more knowledgeable may be led by their desires for self-advancement to bend or break the law. ${ }^{133}$ Thus, a strong policy statement from the management against passing information to other departments, accompanied by an educational program for employees, is considered essential if a Chinese wall is to be even minimally effective. ${ }^{134}$

Despite these measures, Chinese walls in financial institutions have not been free from criticism. ${ }^{135}$ In part, problems have arisen from a failure to adopt, and when adopted to apply, adequate procedures. Some large banks, for example, were slow to establish policies against transfer of information from their commercial banking to their trust departments. ${ }^{136}$ Even when such policies were announced, commercial credit files sometimes remained open to trust department employees. ${ }^{137}$ In other cases, the procedures were adequate but were applied only to a small segment of the full range of confidential information in need of protection. ${ }^{138}$ Occasionally, too, the wolves were left to guard the sheep: individuals who were themselves subject to the rules bore the duty of enforcement and performed the task of distinguishing protected from unprotected information. ${ }^{139}$

129 Herzel \& Colling, supra note 118, at 89.

130 Id. 91.

131 Lipton \& Mazur, supra note 118, at 466.

132 These sanctions include criminal penalties for violation of rule $10 \mathrm{~b}-5$ proscriptions on insider trading.

133 See Hunsicker, supra note 118, at 643-44 \& n.180.

134 Herzel \& Colling, supra note 118, at 88-89.

135 See, e.g., Herman \& Safanda, supra note 118; Note, supra note 118, at 412-13.

136 Herman \& Safanda, supra note 118, at 39.

137 Id.

138 Id.

$139 \mathrm{Id}$. 
Although such problems could be avoided by stricter observance of walling methods, walls in financial institutions have also suffered from defects that may be irremediable. If the bank or firm is small, so that the same employees perform diverse functions, a wall may be impossible to build. ${ }^{40}$ Some mingling of functions may be unavoidable even in large institutions when integrated decisionmaking procedures increase the likelihood that confidential information will be exchanged among higher-ups. ${ }^{141}$ Particular kinds of transactions, such as a firm's investing for its own account in securities concerning which it has acquired inside information, may present temptations too great to resist. ${ }^{142}$ And it may be that structural, procedural, and educational methods all combined are no match for the natural tendency of coworkers to talk shop at company-wide social gatherings and in chance encounters. ${ }^{143}$ At any rate, studies of Chinese walls in financial institutions have found frequent breaches. ${ }^{144}$ Despite these drawbacks, the bulk of considered commentary on the problem endorses the Chinese wall as a significant aid in solving the information conflicts of financial institutions. ${ }^{145}$

\section{B. Financial Walls Compared to Law-Firm Walls}

The experience of financial institutions with Chinese walls indicates that walls are not impermeable barriers to information flow. Although in some respects law-firm walls are similar, important differences exist. On balance, a comparison of financial and law-firm walls suggests that Chinese walls in law firms will successfully impede the flow of confidential information in successive representation cases.

Similarities between financial institutions and law firms make their walls comparable. Like employees of financial institutions, individual lawyers in small law firms may perform potentially conflicting functions. ${ }^{146}$ Large law firms typically have a departmental 643.

140 Herzel \& Colling, supra note 118 , at $91-92$; Hunsicker, supra note 118 , at

141 Herman \& Safanda, supra note 118, at 38.

142 Lipton \& Mazur, supra note 118, at 499-510.

143 Herman \& Safanda, supra note $118,40-41$.

144 See Hunsicker, supra note 118 , at $645-46$ \& n.191.

145 See, e.g., Herzel \& Colling, stura note 118; Lipton \& Mazur, supra note 118; Méndez-Peñate, supra note 118 .

146 For example, in a small firm lacking a departmental structure, a lawyer serving as a trustee may also acquire inside information relating to trust holdings or to publicly traded securities by virtue of his or her corporate law activities. In a large firm, separate trust and corporate departments would render this improbable. 
structure and branches in several locations. ${ }^{147}$ In large firms, however, as in large financial institutions, important decisions are often made by committees whose membership cuts across organizational lines. ${ }^{148}$ Interdepartmental and interbranch transfers of personnel are not uncommon in large firms, and some firms even require departmental rotation by young associates. ${ }^{149}$ Like financial institutions, law firms recruit new business from other departments and encourage firm unity at social gatherings attended by all the lawyers associated with the firm. To the extent that the effectiveness of lawfirm walls depends upon a strict observance of the separation of departments and branches, these similarities suggest that Chinese walls in law firms will suffer the same defects as walls in financial institutions.

Some of the differences between financial institutions and law firms would appear to indicate that walls in law firms will be even less reliable than their financial cousins. The information problems in financial institutions arise because different departments offer different services, whereas in law firms information problems may arise within a single department. Because these problems are inherent when a multiplicity of services is provided, as in financial institutions, financial walls are permanent. By contrast, law-firm walls are typically created after a conflict arises; ${ }^{150}$ they attempt to screen a particular matter, rather than all matters handled by a particular employee or group of employees. The ad hoc and post hoc nature of law-firm walls means that no barrier to the flow of confidential information will be erected until the ethical problem is discovered.

Despite these gloomy indicators, persuasive evidence supports a sunnier forecast for the effectiveness of Chinese walls in successive

147 See generally Survey, supra note 1. For discussion of the structure and organization of small and large firms, see E. SMIGEr, Tre Wall Street Lawyer $171-248$ (1964).

148 See, e.g., Baker \& Botts, Firm Resume (Houston), 1979; Hughes, Hubbard \& Reed, Firm Resume (New York), July 1, 1979, at 2; Morgan, Lewis \& Bockius, Firm Resume (Philadelphia), Fall, 1979, at 2. See generally E. SMrcer, supra note 147 , at $236-39,244$.

149 E.g., Milbank, Tweed, Hadley \& McCloy, Firm Resume (New York), Aug., 1979, at 3 (eight-month rotation); Gaston Snow \& Ely Bartlett, Firm Resume (Boston), Fall, 1979 (two-year rotation); Wolf, Block, Schorr and Solis-Cohen, Firm Resume (Philadelphia), Sept., 1979, at 4 (one-year rotation). See generally E. SAIGEL, supra note 147, at 239-43.

Firms with several branches may have rotation among branches. E.g., Fulbright \& Jaworski, Firm Resume (Houston), June, 1978, at 2.

150 See, e.g., Westinghouse Elec. Corp. v. Kerr-McGee Corp., 580 F.2d 1311, 1321 (7th Cir.), cert. denied, 439 U.S. 955 (1978); Kesselhaut v. United States, 555 F.2d 791, 793 (Ct. Cl. 1977) (en banc). 
representation cases. First, the softness of departmental lines in law firms would be relevant chiefly in concurrent representation cases, in which separate teams of lawyers contemporaneously pursue conflicting representations. But, as explained in part I above,,$^{151}$ in such cases the Canon 5 problems are likely to overshadow the Canon 4 issues, and the Chinese wall defense has little chance of defeating a disqualification. Moreover, studies that show the permeability of financial walls are of questionable relevance to legal walls in successive representation cases, because the conflicts in financial institutions are mostly concurrent, and there is good reason to believe that Chinese walls are more likely to be effective in cases of successive rather than concurrent representation. ${ }^{152}$

Second, the ad hoc nature of law-firm walls operates in successive representation cases to create a greater, not a lesser, likelihood of prevention. Unlike financial walls, law-firms are not used to screen an entire department, but only the individual lawyer or lawyers tainted by reason of their former representations. As the number of people to be walled off grows smaller, the prospects for a successful wall increase. Furthermore, because law firms erect walls with the expectation that their procedures will be subjected to judicial scrutiny upon a motion for disqualification, strict adherence to walling measures may be presumed. The attorneys whose activities are responsible for the screening procedures can also count on testifying under oath concerning their conduct and thus will have every reason scrupulously to observe the wall. In contrast, walls in financial institutions are standard operating procedure, and outside scrutiny is likely to be infrequent.

The validity of the Chinese wall defense, however, does not depend upon a showing that Chinese walls will never be breached. The purpose of the defense-to rebut the presumption of imputed knowledge-will be fulfilled if a Chinese wall is deemed probably effective. Once the wall defense is sustained, a determination based on the probable effectiveness of the wall given all the facts and circumstances of the individual case, ${ }^{153}$ actual breaches can still be proved by the party moving for disqualification. Returning the burden of producing evidence to that party will not require it to disclose the very secrets it wishes to protect; it should be enough, for example, to show the mere occurrence of forbidden conversations, without demonstrating any prejudice resulting from their con-

151 See text accompanying notes 29-34 supra.

152 See text accompanying note 64 supra.

153 See part IV, comprising text accompanying notes 156-65 infra. 
tents. That such a burden is not excessive is demonstrated by Fund of Funds, Ltd. v. Arthur Andersen \& Co. ${ }^{154}$ and Westinghouse Electric Corp. v. Kerr-McGee Corp. ${ }^{155}$ In both cases the party seeking disqualification established a breach in the Chinese wall. Viewed in this light, the preceding comparison of walls in financial institutions and in law firms establishes that, in general, law-firm walls in successive representation cases have a likelihood of effectiveness sufficient to oblige courts to give the Chinese wall defense serious consideration.

IV. Factors Influencing Acceptance of the Chinese Wall Defense in Particular Cases

Although part III established the general effectiveness of Chinese walls in successive representation cases, it is not suggested that the Chinese wall defense is thereby entitled to recognition in every case in which it is raised. A case-by-case approach is necessary because the determination of the risk of disclosure or misuse of client confidences is a factual one that will vary with the circumstances. In some cases, it may be that a court should reject the defense as unlikely to be effective even though no actual breach has been shown. To pose an extreme example: suppose that a client $X$ had long been represented by law firm $A$, which had at the time ten lawyers. Dissatisfied with $A$ 's service, $X$ finds new counsel. One month later, firm $A$ is retained by client $Y$ to sue $X$ in a matter closely related to $A$ 's former representation of $X$. Although it is clear given the history of $A$ 's relationship to $X$ that all ten lawyers who worked at firm $A$ during that time would be disqualified, $A$ has since hired two new lawyers, neither of whom has ever worked on matters relating to $X$. Having read the first three parts of this Comment, firm $A$ decides that it will not be disqualified if it constructs a wall around the ten original lawyers and entrusts the litigation to its two new attorneys. Everyone is instructed not to discuss the litigation with the new attorneys, but no measures are taken to restrict access to the many files that have accumulated over the years respecting $X$. In such a case, a court would be justified in disqualifying firm $A$ entirely, without requiring $X$ to prove any actual breach of the wall. The probability of a breach is high, and the prejudice to the underlying case likely to be great. 
No precise formula exists for determining when a wall should be accepted. But a number of factors can be articulated that will bear on that determination. Both the nature of the information problem and the "architecture" of the wall will affect the likelihood of a breach. In addition, the former will also determine the gravity of the prejudice to the party moving for disqualification.

(1) The substantiality of the relationship: assuming that the former and current "matters" are "substantially related" so as to disqualify at least one attorney, the degree of substantiality will influence the gravity of the potential prejudice involved and thus figures in the decision whether to disqualify the firm. The more closely related the matters are, the greater the possible prejudice. ${ }^{150}$

(2) The time lapse between the matters: when the former representation is a recent one, recollection of confidences and secrets will be greater, files relating to the matter will more likely be available, and the likelihood of a breach will be higher than if the former representation took place in years gone by. ${ }^{157}$

(3) The size of the firm: in small firms the presumption of imputed knowledge is more realistic than in large firms. ${ }^{\text {t58 }}$

(4) The number of disqualified attorneys: when the attorneys to be walled off are few, the likelihood of success is great; the fewer the number of actual contacts, the smaller the opportunity for disclosure.

(5) The nature of the disqualified attorney's involvement: assuming that the tainted attorney's involvement is sufficient to disqualify him or her, the extent of his or her knowledge may affect the gravity of the prejudice. A junior associate who worked on peripheral legal issues is less likely to be privy to potentially damaging confidences and secrets than a senior partner heavily involved in conducting the litigation. ${ }^{159}$ Likewise, a government attorney

156 See, e.g., Silver Chrysler Plymouth, Inc. v. Chrysler Motors Corp., 518 F.2d 751 (2d Cir. 1975); T.C. Theatre Corp. v. Warner Bros. Pictures, 113 F. Supp. 265, 268-7I (S.D.N.Y. 1953).

157 See, e.g., Westinghouse Elec. Corp. v. Rio Algom Ltd., 448 F. Supp. 1284, 1309-10 (N.D. III.), rev'd sub nom. Westinghouse Elec. Corp. v. Kerr-McGee Corp., 580 F.2d 1311 (7th Cir.), cert. denied, 439 U.S. 955 (1978); Liebman, supra note 9 , at 1016.

158 See, e.g., Gas-A-Tron v. Union Oil Co., 534 F.2d 1322 (9th Cir.) (per curiam), cert. denied, 429 U.S. 861 (1976); Silver Chrysler Plymouth, Inc. v. Chrysler Motors Corp., 518 F.2d 751 (2d Cir. 1975); Liebman, supra note 9, at 1017-18, 1036; Intra-Firm Conflicts, supra note 2, at 1068-70.

${ }_{159}$ See, e.g., NCK Org'n v. Bregman, 542 F.2d 128, 133 n.7 (2d Cir. 1976); Gas-A-Tron v. Union Oil Co., 534 F.2d 1322, 1324 (9th Cir.) (per curiam), cert. denied, 429 U.S. 861 (1976); Silver Chrysler Plymouth, Inc. v. Chrysler Motors 
with merely formal or supervisory responsibility will probably lack knowledge of the details of cases as compared with an attorney involved on a day-to-day basis. ${ }^{160}$

(6) The timing of the wall: a Chinese wall erected as soon as the potential for disclosure or use of confidences arises has a better chance of success than one created after the fact.

(7) The features of the wall: at a minimum, walls should prohibit discussion of sensitive matters, limit the circulation of sensitive documents, and restrict access to files. ${ }^{161}$ A strong firm policy against breaching the wall with a threat of sanctions, measures to prevent the disqualified attorneys from deriving any compensation from the representation, and organizational, physical, and geographic separation are all ingredients that fortify a Chinese wall. ${ }^{162}$

In weighing those factors the question must always be-does the Chinese wall reduce the potential for prejudicial misuse of confidences and secrets to an acceptable level? In certain circumstances,

Corp., 518 F.2d 751, 753-54, 756-57 (2d Cir. 1975); Redd v. Shell Oil Co. [1974-2] Trade Cas. I 75,392, at 98,278 (D. Utah 1974), rev'd in part on other grounds, 518 F.2d 311 (10th Cir. 1975); Silver Chrysler Plymouth, Inc. v. Chrysler Motors Corp., 370 F. Supp. 581, 588 (E.D.N.Y. 1973), affd, 518 F.2d 751 (2d Cir. 1975); Liebman, supra note 9 , at 1036.

160 See, e.g., Armstrong v. McAlpin, 606 F.2d 28, 33 (2d Cir. 1979), rehearing en banc granted, No. 79-7042 (Dec. 12, 1979); Kesselhaut v. United States, 555 F.2d 791, 793 (Ct. Cl. 1977) (en banc).

161 See, e.g., Kesselhaut v. United States, 555 F.2d 791, 793 (Ct. Cl. 1977) (en banc); Armstrong v. McAlpin, 461 F. Supp. 622, 624 (S.D.N.Y. 1978), rev'd, 606 F.2d 28 (2d Cir. 1979), rehearing en banc granted, No. 79-7042 (Dec. 12, 1979).

162 See, e.g., ABA OpInIoN 342, supra note 6, reprinted in 62 A.B.A.J. 517, 521 (1976); Herzel \& Colling, supra note 118, at 88-91; Liebman, supra note 9, at 1037; Revolving Door Proposal, supra note 36, at 56-58.

Of course, the factors listed in the text need not be the only ones a court uses in considering the validity of a wall. Several authorities require or suggest that the isolated attorney and members of the firm take oaths affirming the fact of isolation. E.g.s 31 C.F.R. $\$ 10.26$ (c)(2) (1978) (IRS post-employment regulations); see NYC BaR OpINION 889, supra note 36, reprinted in 31 Record 552, 570 (1976); Note, Conflicts of Interest and the Former Government Attorney, 65 GEo. L.J. 1025, 1047-48 (1977). Another relevant factor might be the manner in which the firm obtained the business. For instance, under SEC post-employment regulations, it will be considered significant that:

The firm had a preexisting securities law practice prior to the arrival of the disqualified attorney;

The matter was previously the subject of consideration by the firm or the client was already advised by the firm;

In cases where the matter or client became the subject of consideration by the firm subsequent to the firm's employment of the lawyer individually disqualified, that the matter was not brought to the firm because of the disqualified attorney.

17 C.F.R. $\$ 200.735-8$ (e) (1979). See also 31 C.F.R. $\$ 10.26$ (c)(1)(i), (ii) (1978); NYC BAR OPINION 889, supra note 36 , reprinted in 31 ReCORD 552, 570-71 (1976). 
nonethical considerations may come into play and lower the threshold for the acceptance of Chinese walls. When the disqualified lawyer is a former government attorney, ${ }^{163}$ or a young associate incapacitated by his or her affiliation with a large law firm, ${ }^{164}$ public policies surrounding the mobility of attorneys render firm disqualification more undesirable than otherwise. If disqualification of the firm would render effective representation unavailable as, for example, when the "firm" is a legal aid office, Chinese walls should receive more favorable treatment. ${ }^{165}$ Surely other policies will be found to exert a similar influence. In any particular instance the question should be whether these countervailing policies are strong enough in the circumstances of the case to render a higher risk of prejudice acceptable.

\section{Conclusion}

Indiscriminate application of the firm-disqualification rule-a rule fashioned in an era when law firms were small and intrafirm relations informal-is no longer viable in the complex world of large law firms. In particular, it is unrealistic to adhere to an irrebuttable presumption that a lawyer shares the confidences and secrets of a client with all the other lawyers in his firm. Although by no means a panacea for the many ethical problems presented by contemporary legal practice, the Chinese wall defense in some cases

163 See, e.g., Kesselhaut v. United States, 555 F.2d 791, 793 (Ct. Cl. 1977) (en banc); United States v. Standard Oil Co., 136 F. Supp. 345, 360-63 (S.D.N.Y. 1955); ABA OpInxon 342, supra note 6, reprinted in 62 A.B.A.J. 517 (1976); Kaufman, supra note 13.

164 See, e.g., Silver Chrysler Plymouth, Inc. v. Chrysler Motors Corp., 518 F.2d 751 (2d Cir. 1975); City of Cleveland v. Cleveland Elec. Illum. Co., 440 F. Supp. 193 (N.D. Ohio), aff'd mem., 573 F.2d 1310 (6th Cir.), cert. denied, 435 U.S. 996 (1978); Intra-Firm Conficts, supra note 2, at 1066-67.

165 See, e.g., Aronson, supra note 9, at 855-58; cf. Bonus Oil Co. v. American Petrofina Co., [1975-1] Trade Cas. If 60,315, at 66,267 (D. Neb. 1975) (placing greater burden on party moving for disqualification would, in some cases, protect "the access of smaller and less privileged economic units of our society to quality legal representation without contributing to unwarranted breaches of client confidences") (citing Silver Chrysler Plymouth, Inc. v. Chrysler Motors Corp., 370 F. Supp. 581 (E.D.N.Y. 1973), aff'd, 518 F.2d 751 (2d Cir. 1975)).

In a recent opinion, the $A B A$ decided to endorse screening to allow members of boards of legal services programs and their firms to represent parties adverse to those represented by program staff lawyers. ABA CoMm. ON ETHICS \& Professional Responsmility, OpInIONS, No. 345 (1979), reprinted in 65 A.B.A.J. 1558 (1979). The opinion recognized "the extreme value of having active practitioners ... serve as board members," and "noted that in some smaller communities it is impossible to secure qualified lawyer-members for boards who would not be involved from time to time representing clients opposing persons represented by program staff lawyers." Id. 1559. The committee concluded "that the compelling need for resources, not the least of which is strong interest in legal services and participation on program boards by active practitioners, to provide legal services for the indigent outweighs the risk of any possible appearances of impropriety." Id. 
can rebut the presumption of imputed knowledge and thereby save a law firm from disqualification. Chinese walls should not be relied upon in cases of concurrent representation, in which the conflict of loyalties addressed by Canon 5 is paramount, but in successive representation cases the Chinese wall defense offers protection from disqualification of a law firm based on Canon 4 difficulties.

Applauded as a workable solution to conflicts in financial institutions, Chinese walls are capable, in general, of effectively preventing the disclosure and misuse of confidential information within law firms. The success of the defense, however, will depend upon the facts and circumstances of each case. This Comment has articulated a number of factors to be considered when appraising a Chinese wall, including (l) the substantiality of the relationship between the former and current matters, (2) the time elapsing between the matters, (3) the size of the firm, (4) the number of tainted attorneys, (5) the nature of the disqualified attorney's involvement in the former matter, (6) the speed with which the wall is erected, and (7) the strength of the wall. In addition to these seven criteria, all bearing on the risk of prejudicial disclosure or misuse, several extrinsic policies may work to tip the balance against firm disqualification. In the former government attorney cases, the government's need for qualified lawyers must be considered. Concern for the mobility of young attorneys will also be a factor militating against disqualification.

Recognition of the Chinese wall defense thus offers a practicable solution to a growing problem of legal ethics. Without detracting from the ethical standards of the legal profession, expanded use of Chinese walls will help to remove artificial obstacles to the job mobility of attorneys, private and public, while securing to clients the maximum right to counsel of their choice. 